Citation: M. Claverie, M. Notaro, F. Fontaine, J. Wery (2020) Current knowledge on Grapevine Trunk Diseases with complex etiology: a systemic approach. Phytopathologia Mediterranea 59(1): 29-53. doi: 10.14601/ Phyto-11150

Accepted: February, 18, 2020

Published: April 30, 2020

Copyright: (c) 2020 M. Claverie, M. Notaro, F. Fontaine, J. Wery. This is an open access, peer-reviewed article published by Firenze University Press (http://www.fupress.com/pm) and distributed under the terms of the Creative Commons Attribution License, which permits unrestricted use, distribution, and reproduction in any medium, provided the original author and source are credited.

Data Availability Statement: All relevant data are within the paper and its Supporting Information files.

Competing Interests: The Author(s) declare(s) no conflict of interest.

Editor: Hanns-Heinz Kassemeyer, Staatliches Weinbauinstitut Freiburg, Germany.
Review

\section{Current knowledge on Grapevine Trunk Diseases with complex etiology: a systemic approach}

\author{
Marion ClaVERIE ${ }^{1, *}$, Martin NOTARO ${ }^{1}$, Florence FONTAINE ${ }^{2}$, \\ JACQUES WERY ${ }^{3}$ \\ ${ }^{1}$ Institut Français de la Vigne et du Vin, Institut Rhodanien, 84100 Orange, France \\ ${ }^{2}$ Structure Fédérative de Recherche (SFR) Condorcet-FR CNRS 3417, Université de Reims \\ Champagne-Ardenne, Unité de Recherche Résistance Induite et Bioprotection des Plantes \\ EA 4707, BP 1039, (Cedex 2), F-51687 Reims, France \\ ${ }^{3}$ SYSTEM Montpellier SupAgro, Inra, Cirad, IAMM-CIHEAM, Université Montpellier, \\ France \\ ${ }^{*}$ Corresponding author: marion.claverie@vignevin.com
}

Summary. Among all causes of grapevine decline, Grapevine Trunk Diseases (GTDs) are major concerns for grape growers. This paper reviews knowledge and proposes hypotheses on two major GTDs, esca and Botryosphaeria dieback, and assembles a conceptual model. The objective was to collect information into a sequence, from grapevine nursery propagation processes, through foliar symptom expression, to plant death in mature vineyards. Pathogen infection and colonization steps in woody vine tissues, and the hypotheses that have been formulated to explain the outburst of foliar symptoms, are reported and discussed. Factors that could aggravate or repress GTD symptoms and incidence expansion are also addressed. Vine physiology and pathology together could expand understanding of these diseases. Knowledge and hypotheses that need validation are summarized, and a conceptual model is proposed to explain the occurrence of symptoms and the influencing factors. The model could be useful to cope with the complexity of GTDs, and as a starting point for research to unravel knowledge gaps and suggest new disease management strategies.

Keywords. Esca, Botryosphaeria dieback, foliar symptoms, impacts, hypotheses, conceptual model.

\title{
INTRODUCTION
}

Grapevine Trunk Diseases (GTDs) are caused by several fungi belonging to nine different families (Mondello et al., 2018). These pathogens cause wood discolouration and necroses, different foliar symptoms, yield damage, and subsequent death of shoots, canes, spurs and whole grapevines (Bertsch et al., 2013; Gramaje et al., 2018; Guérin-Dubrana et al., 2019). GTDs are major causes of grapevine decline, especially in European countries. These diseases can be divided into different syndromes, depending on symptoms, 
the families of pathogens involved (often related to geographical areas), environmental factors and vine age. Major GTDs on adult vines include esca, Botryosphaeria dieback, and Eutypa dieback. On young vines, main GTDs are Black foot disease, Petri disease or diebacks due to Botryosphaeriaceae, Verticillium or Fusarium (Mugnai et al., 1999; Surico, 2009; Larignon, 2016; Gramaje et al., 2018).

Wood inhabiting fungi and their related necrosis in the trunks and arms of vines are considered to be the agents associated with the different foliar symptom expressions, but in some GTDs, there is no clear evidence of their role in symptoms expression. All the associated pathogens have been proven to provoke wood symptoms when inoculated to grapevine wood (Mugnai et al., 1999; Larignon et al., 2009a; Bertsch et al., 2013), but Koch's postulates have not always been completed to reproduce foliar symptoms. Foliar symptoms of Eutypa dieback (stunted shoots, witch's brooms) have been fully reproduced on young or mature vines after wood inoculation with Eutypa lata (Sosnowski et al., 2007), those of esca and Botryosphaeria dieback have not. Only two papers (Sparapano et al., 2001; Feliciano et al., 2004) have reported reproducing foliar symptoms on mature vines, in 20 years of research, and the etiology of these diseases has not been completely elucidated (Mondello et al., 2018).

Grapevine decline is a major problem for French grape growers and winemakers. In 2016, a National Plan against Vine Decline (Plan National Dépérissement du Vignoble; PNDV) has given special attention to the issue, and has helped to determine the causes, and propose sustainable solutions for growers, to counteract decline. Decline can be described as abnormal reduction in vineyard productivity and longevity, related to multiple causes (biotic and abiotic factors). GTDs are one of these causes. Although long-recognized (Chiarappa, 2000; Surico, 2009; Larignon, 2016), GTD incidence is increasing in France since the 2000s and has reached an annual average of 13\% (Grosman and Doublet, 2012; Bruez et al., 2013). In Europe, GTD incidence could be similar, with reports fluctuating from 1.8 to $10.5 \%$ in Spain and from 8 to $19 \%$ in Italy. Incidence of these diseases has reached 60 to $80 \%$ in some old vineyards in Tuscany, Apulia and Sicily. Outside Europe, $30 \%$ of old vineyards in Argentina are affected, and considerable economic losses due to GTDs have been reported in the United States of America, Australia and New Zealand (De La Fuente et al., 2016).

The present review aims to provide increased understanding of the etiology of "tiger stripe" foliar symptoms (FS) and apoplexy, two damaging symptoms frequently found in France and Europe on mature grapevines. The apoplexy form involves sudden vine death while tiger stripe symptoms are a milder form, with interveinal discolourations and necrosis on leaf blades, affecting all or part of vine foliage (Mugnai et al., 1999; Lecomte et al., 2012). FS can lead, for the more severe form, to complete leaf wilting and leaf fall. Grape bunches may also be affected, either directly or indirectly, leading to berry shriveling, and yield and quality losses (Calzarano et al., 2004; Fontaine et al., 2016; Claverie et al., 2017), as well as drying up of canes, spurs and eventually whole plants (Mondello et al., 2018; Guérin-Dubrana et al., 2019).

On adult vines, tiger stripes and apoplexy are associated with esca and to some extent, in France, and for tiger stripes, to Botryosphaeria dieback although this association has been controversial (Dubos et al., 2001; Surico et al., 2006; Úrbez-Torres, 2011; Lecomte et al., 2012). Esca has been assumed to be a complex of diseases, with symptoms associated to Grapevine Leaf Stripe Disease (GLSD) and esca proper (Surico, 2009). In this review, the terms esca and Botryosphaeria dieback are used to refer to the diseases potentially responsible of tiger-stripe like symptoms or apoplexy. Because Eutypa dieback symptoms are better understood, and although this disease also affects grapevine productivity, it is not within the scope of this review.

FS are associated with a complex of fungi whose roles and associations are not always clear, and these may be altogether present in a single vine and influenced by genotypic and environmental factors. Fungi can be wood-inhabiting but the detrimental symptoms they cause for growers occur in the foliage at some distance from the infections. FS may be absent for many years although necroses and cankers are present in vine trunks as latent infections, and then can fluctuate from year to year (Calzarano et al., 2018). For these reasons, esca and Botryosphaeria dieback are regarded as complex diseases (Mondello et al., 2018). Understanding the host/pathogen/environment triangle is critical to explain the occurrence of FS (Fischer and Peighami-Ashnaei, 2019).

Because of the complexities of these diseases, a systemic approach to understand their etiologies has been taken, focusing on fungi and on vine physiology and related factors to explain the emergence of disease symptoms. This approach consisted of reviewing knowledge on esca and Botryosphaeria dieback to present a sequence of events from young grafted plants to the death of mature vines, using conceptual modelling (Lamanda et al., 2012). This approach has two differences from a traditional review. First, it is set to provide a global overview of the syndrome indicating the 
interactions between many factors. For this reason, the approach fails to provide a detailed exploration of individual aspects, but relies on existing reviews by specialists. Secondly, in addition to existing data on these diseases, we have attempted to fill knowledge gaps, making assumptions supported either by published research (e.g. agronomy and physiology) on grapevine subjects other than GTDs, or from forest decline and forest pathology disciplines. A significant principle for conceptual modelling that we have used is 'parsimony', which begins at the general level and moves to the specific. Complexity is added only if necessary in response to assumptions (Lamanda et al., 2012). The conceptual model was submitted to an expert group to challenge the hypotheses developed.

This review is organized in two parts: the first presents the hypothetical sequence of events leading to FS and vine death, and the second discusses the major influencing factors that are likely to aggravate or repress this sequence. Figures supporting each part are also presented to summarize the hypothetical sequence of events and the different interference drivers.

\section{FROM PLANTATION TO SYMPTOM EMERGENCE AND GRAPEVINE DEATH, THE KEY STEPS}

\section{Step 1: Infection}

To contaminate vine tissues, it is assumed that GTD fungi need fresh wounds as entry points, as few pathogens colonize hosts without entry points, because of host protection layers such as periderm and rhytidome (Pearce, 1996). Each successful infection initially occurs with the simultaneous occurrence of outer inoculum and a wound, although it is unclear whether some fungi can enter through uninjured tissues (Feliciano and Gubler, 2001) or infections could initiate from endophytic propagules after being triggered by some environmental changes, as occurs in forest trees (Baum et al., 2003). The term 'outer inoculum' can be defined as the air-borne or soil-borne propagation forms of GTD fungi (spores or mycelium) that can remain on the surface or in the vicinity of the vine or wood debris, or on alternative hosts in the field or during nursery processes. In contrast, 'inner inoculum' characterizes GTD fungi that have penetrated and developed within grapevine tissues.

\section{Outer inoculum}

Phaeomoniella chlamydospora (Pch), Phaeoacremonium minimum (Pmi) and Fomitiporia mediterranea
(Fmed) are the three fungi commonly associated with the esca complex, but Eutypa lata (El), which causes Eutypa dieback and several Botryosphaeriaceae species (e.g. Diplodia seriata (Ds) and Neofusicoccum parvum (Np)) are also frequently retrieved from the wood of vines showing FS.

The life cycles of these pathogens have been thoroughly documented. Larignon and Gramaje (2015) presented a review which compiled for each fungus its mode of dissemination, infection points, favourable climatic conditions and period of wound susceptibility, depending on the region of the world. Spore release is commonly associated with a rain event, but the best periods for inoculum dissemination can differ between fungi. In France Pch spreads throughout the year, and infections occur mainly in winter through pruning wounds (Larignon et al., 2009a; Larignon and Gramaje, 2015), whereas Pmi is mostly present during the vegetative host period and infections on pruning wounds occur mostly after grapevine budburst. Both of these fungi can also enter vines through green stems during spring (Davy et al., 2011). Infections by Botryosphaeriaceae are reported to occur following rain events, but during periods from mostly winter to throughout the year, depending on the region (Úrbez-Torres, 2011). Some Botryosphaeriaceae species can penetrate vines through pruning wounds, especially after bud bleeding, but some can also enter through wounds on green stems in spring and summer (Molot et al., 2006; Reis et al., 2019).

Infection is also probably influenced by the intrinsic abilities of each fungus, and their modes of wood colonization. An hypothesis formulated for esca was that the fungi act in sequence, where colonization is initiated by pioneer fungi, as occurs for forest trees (Shigo, 1979; Boddy and Rayner, 1983; Pearce, 1996). Pioneer fungi could survive greater amounts of phenolics and other antimicrobial compounds than decay fungi. Decay fungi start acting on host tissues when pioneer fungi have sufficiently "detoxified" the plant tissues. For esca, the hypothesis was that Pch and Pmi colonize first, and then Fmed can invade (Larignon and Dubos, 1997; Mugnai et al., 1999). Valtaud et al. (2009) also reported that Pch and Pmi have specific life traits, enzymatic ones in particular, leading them to hypothesize that Pch could be more specialized in toxin production (naphtalenones, phenolics, polysaccharides) and Pmi more efficient at degrading and colonizing tissues. Another hypothesis (Mugnai et al., 1999) was that these fungi, included the basidiomycete fungus Fmed, can interact but can also act as primary pathogens, as shown by experimental data (Sparapano et al., 2001; Surico, 2009). 
Despite information on pathogen life cycles, there is little literature on the diversity and amounts of the outer inoculum in vineyards, and on variability between neighbouring plots, or between regions. Knowing this would be important to indicate if outer inoculum is a limiting factor, and vineyard or region specificities of different Botryosphaeriaceae and Pch/Pmi/Fmed compositions in the outer inoculum. However, there is a lack of validated monitoring methods to measure these effects, at least in Europe.

\section{Wounding}

Grapevine is a liana that is pruned every year, in winter. On an adult vine, this results in many wounds between the 1-year-old wood (canes as lignified shoots) and 2-year, 3-year or older wood (spurs, arms, trunk). Grosclaude (1993) demonstrated the double impact of pruning a fruit tree: first, connection between the woody tissues and the atmosphere, characterized by drying and embolizing vessels and the development of callose or gel deposits; and second, the aspiration of air and particles (including spores) inside the wood to, generally, a few centimeters depth.

While other wound types (cracks or wounds caused by biotic or abiotic factors) can also play roles, winter pruning wounds are thought to be the major entry points for GTD fungi. Considerable research has been carried out on the susceptibility of pruning wounds to pathogen infections. This differs depending on the fungus, pruning date (early or late in winter) and climatic conditions, and consequently the year and geographical region (Larignon, 2011; Larignon and Gramaje, 2015; Mondello et al., 2019). Wounds generally stay susceptible for several weeks and up to 4 months (Gramaje et al., 2018). Pruning type and "quality" can also have indirect consequence on GTDs, as these factors create specific wood necroses and decay in the perennial host organs (see below).

Grafting and production processes in grapevine nurseries as well can result in wounding that has been shown to provide infection points for GTD fungi. This has been largely documented during the last decade, and outlined by Gramaje and Armengol (2011) and Gramaje et al. (2018). When a ready-to-sell nursery plant is dissected, most of the GTD fungi can be detected (Vigues et al., 2007; Larignon et al., 2009b; Gramaje and Armengol, 2011; Spagnolo et al., 2011). In France, Pch and Botryosphaeriaceae are the major fungi isolated from plants, Pmi is less frequently isolated, and Fmed or El have never been detected. These fungi have been shown to be present on rootstock and scion canes before grafting, but with much lower frequency than on ready-to-sell plants. This suggests that some steps in the nursery processes (rehydrating, grafting, callusing and in nursery fields) are key infection steps that increase the presence of GTD fungi. This has been shown to be the case in different countries (Aroca et al., 2010; Vigues et al., 2012; Vigues et al., 2013; Gramaje and Di Marco, 2015; Gramaje et al., 2018).

It would be important to determine the respective contributions of the initial infections in nurseries from year-to-year accumulation of infections in vineyards to the sanitary status of mature vines.

Yobregat et al. (2018) showed that plants initially free of GTD fungi at planting (from green grafting techniques) are repeatedly infected from in-field infections, and show the same amounts of inner inoculum as traditionally-produced plants within 3 years after planting. This suggests that the contribution of outer inoculum to the wood infections can be important in some cases. This also highlights the importance of protecting the wounds from field infections (Mondello et al., 2018), although this is difficult, time-consuming and expensive (Bertsch et al., 2013; Mondello et al., 2019).

Another related question is the contribution of wounds during the first years of grapevine life (from planting year up to 2- to 5-year-old plants), compared to wounds made during later decades in older vines. In young vines, pruning wounds (and possibly desuckering wounds as well) provide dead wood and access for fungi directly to the cores of the future trunks and arms.

These two points are important, in order to determine the respective contributions of nursery procedures, management of young vineyards and further repeated infections on the sanitary status of mature vines.

\section{Step 2: Colonization/defence; host/pathogen relationships}

Once GTD fungi have infected the woody tissues, the colonization phases by fungal communities begin, and these induce the formation of discoloured and decayed host wood. This step leads to accumulation of potential inner inoculum of GTD pathogens, and restricts vine living and functional wood.

\section{Tree defence concepts}

Literature on forest tree pathology gives a key contribution. At basic process levels, knowledge from trees can be used as a basis for assumptions of vineyard functioning (Lamanda et al., 2012). Reaction zones in trees are created after infections, at the interface of injured and functional wood, and these zones restrict the path- 
ogens to particular woody zones. The reaction zone concept, and more generally the defence mechanisms that develop after infection to limit the pathogen colonization, have been well-documented and conceptualized in forest trees (Shain, 1971; Boddy and Rayner, 1983; Pearce, 1996, 2000). To simplify, we here use the reaction zone concept to describe the place where active vine defences and mechanisms of fungal colonization are observed. Progression of this reaction zone and subsequent degradation of tissues are assumed to be due to alterations of micro-environments, or to the microfloral evolution and dynamics. Resistance mechanisms can also interfere, as reported by the CODIT model (Shigo, 1979). This considers four types of barriers ("walls") that restrict pathogen progression. These "walls" are related to wood anatomy (parenchyma rays, wall 3, and annual rings, wall 2), or to active vine responses to pathogenic fungi. Wall 1 is the synthesis of gums and phenolics in the host vessels to longitudinally restrict the fungus, and wall 4 is reinforcement of the cambium zone, so that growth of functional wood rings can occur ahead of the infections. Pearce (1996) presented a detailed review of the different concepts in forest trees, and this has been also discussed in relation to esca of grapevine (Mugnai et al., 1999).

\section{Characteristics of GTDs-associated fungi}

Fungi associated with GTDs show different abilities to colonize wood that can be categorized into wood degrading ability, defence compounds or ability to counteract the production of grapevine metabolites. Active compounds synthesized by fungi and grapevines have been intensively studied, benefitting from the recent progress in molecular techniques used to characterize fungi and their biosynthesis pathways or interactions. GTD fungi have different enzymatic abilities for degradation of lignin, pectin or starch.

Mature xylem vessels of grapevines are dead cells, composed of cellulose surrounded by hemicellulose and lignin, and pectic compounds, conferring mechanical resistance. These walls have different layers (from the outside to the inside of cell): middle lamella then primary and secondary walls each showing different composition of lignin, cellulose, hemicellulose and pectin. This level of detail is important for understanding the pathogen colonizing processes, since the intrinsic enzymatic abilities of each fungus differ and could assist with developing a multi-dimensional model of grapevine wood degradation. Full characterization of fungus modes of action exists for forest trees, and was outlined by Schwarze and Baum (2000).
The GTD pathogens Pch and Pmi show poor lignolytic activity but strong abilities to degrade starch (Mugnai et al., 1999). Pch mainly occurs in host vessels (Larignon and Dubos, 1997; Troccoli et al., 2001; Cottral et al., 2004; Valtaud et al., 2009; Fleurat-Lessard et al., 2010; Mutawila et al., 2011; Pierron, 2015) and is unable to degrade secondary walls, but can digest membranes and thus progress into xylem vessels, potentially in the presence of tyloses and gum. Pch is also unable to pass through annual rings (Larignon, 2004). Pmi has been less extensively studied; it is found mainly in the fibers (Valtaud et al., 2009; Pierron, 2015) where it can degrade secondary walls (Fleurat-Lessard et al., 2014), as well as El. Both of these fungi can be characterized as soft rot agents (Larignon et al., 2009a; Pouzoulet, 2012) whereas Pch would rather be like a blue stain fungus (Larignon, 1990; Larignon et al., 2009a). The mode of action of Botryosphaeriaceae is poorly documented, although Gómez et al. (2016) showed lignolytic activity in an uncharacterized species of Botryosphaeriaceae retrieved from vineyard surveys. Some research still in progress will probably provide more information about Botryosphaeriaceae fungi and their action in GTDs. Fmed is a basidiomycete considered as a white rot (decay) fungus, with high lignolytic activity and ability to completely degrade woody tissues (Mugnai et al., 1999).

In addition to predicting the architecture of wood necrosis, increased knowledge on fungus modes of action and on trophic relationship in host tissues could assist prediction of impacts of the fungi on grapevine carbon (C) metabolism (Oliva et al., 2014). Depending on the trophic interactions between host and fungi (including biotrophs, necrotrophs, vascular pathogens or a mix of these) the impact on $\mathrm{C}$ metabolism may come from direct consumption by the fungus, such as enhanced costs for defences or for repair, negative impacts on photosynthesis or hydraulic failure. Knowledge on GTD fungi has not determined their trophic modes of action, even where their non-biotrophic nature can be postulated. Knowing this could give clues for unravelling the mechanisms underlying pathogen colonization and their impacts on the grapevine decline.

\section{Multiple conditions determining wood colonization}

Apart from the scheme of one-way progression of fungi presented above, the host/pathogens relationships found in the reaction zones could be multiple dialogues between vines and fungi, fungi and fungi (species and strains), fungi and associated microflora (fungi and bacteria), and the whole is likely to be modulated by environmental conditions. 
Three drivers can, theoretically, determine the extent of wood colonization by fungi:

- Relationships within trunk microbiota. Predominance of one pathogen over another, co-action of two micro-organisms or of two strains: microbiota can be considered as complex networks where microbes interact with each other, with the environment determining specific conditions that can be more or less conducive to pathogenicity (Brader et al., 2017). For GTDs, the grapevine wood microbiota is particularly rich (Hofstetter et al., 2012; Bruez, 2013; Pinto et al., 2014), and several studies suggest that interactions inside the community of GTD fungi, as well as vine physiology and the environment, can strongly affect the behaviour of each fungus alone (Bruno and Sparapano, 2006a; Oliveira et al., 2009). Bruez et al. (2014) showed that microflora composition inside visually healthy trunk tissues varies during the year. This composition also evolves in time and with plant tissues. Diversity of the microflora is greater on young vines (Rey et al., 2011; Hofstetter et al., 2012; Bruez, 2013) and in visually healthy tissues rather that in decayed tissues.

- Structural or micro-environmental conditions in trunks. Although cell walls are mainly used as substrates for fungus nutrition, some fungi can likely have specific nutritional requirements (Pearce, 1996). Soluble compounds in parenchyma or in sap can also influence the progression of fungi. These compounds include amino acids (Magnin-Robert et al., 2014), soluble sugars (Spagnolo et al., 2014a) or ions (e.g. iron (Di Marco et al., 2001; Osti and Di Marco, 2010). Temperature (Sosnowski et al., 2011; Landi et al., 2012; Pontini et al., 2014) and pH (Surico et al., 2001; Valtaud et al., 2009) have also been shown to be important factors determining wood colonization by fungi. In addition, the micro-environmental theory (Boddy and Rayner, 1983), developed for forest trees, is also pertinent considering. This assumes that the water content of woody tissues close to the host/ pathogen reaction zones can alone explain fungus progression inside tree trunks, as fungi follow the dehydrated and oxygen rich zones that occur along the reaction zones close to wounds.

- Active vine defences. Living xylem of grapevine, like other woody perennials, is composed of dead (vessels, fibers) and living cells (paratracheal and ray parenchyma cells), the whole xylem being submitted to reaction zones and CODIT walls of compartmentalization following infection and colonization by wood pathogens. Reaction zones are regions of active host responses where active compounds are released to slow the progression of pathogens (Pearce, 1996), thanks to the living cells they host and that co-exist in the vicinity of dead cells. The first active defence is tylosis formation inside the vessels. Tyloses are outgrowths of membranes of neighbouring parenchyma cells, inside each vessel through the pits, and are generally reinforced by gels or gums. This first defence response to the presence of a pathogen slows longitudinal progression (del Rio et al., 2001; Troccoli et al., 2001; Larignon, 2010; Pierron, 2015; Gómez et al., 2016). Among the defences commonly observed in forest trees (Pearce, 1996; Yadeta and Thomma, 2013; Smith, 2015), lignin or suberin deposits reinforce cell walls in the injured zones. Tannins or other phenolics (e.g. phytoalexins and 'pathogenesis related' (PR) proteins synthesized around zones exposed to slow radial infection), trap some fungus enzymes or prevent sporulation. Similar compounds have also been detected in GTDs (del Río et al., 2004; Rolshausen et al., 2008; Bertsch et al., 2013; Pouzoulet et al., 2013; Fontaine et al., 2016). Responses to GTD fungi are thought to occur due to PAMP-triggered immunity (PTI). Phytoalexins, compounds from the phenylpropanoid pathway such as resveratrol or viniferin, are found in greater amounts in tissues after infection by GTD fungi (Amalfitano et al., 2000; del Rio et al., 2001; Bruno and Sparapano, 2006b; Martin et al., 2009; Spagnolo et al., 2014b). Phytoalexins could inhibit fungal growth and colonization, as well as block some metabolites produced by the fungi during infection, or interfere in oxido-reduction reactions (Gómez et al., 2016). In addition to the active defence processes implemented by vines, the anatomy of the wood could also be important. Density of parenchyma rays and arrangement in space, could contribute to increased active responses to infection (Pearce, 1996). The diameter of vessels (Pouzoulet et al., 2014) could also be a factor (see below).

Necrotic decayed and discoloured wood, and their consequences

The ongoing host-pathogen process ends with the formation of discoloured and decayed zones in the wood. In grapevine, these "necroses" are observed in the wood cylinders on any adult plant, even in the absence of FS (Maher et al., 2012; Spagnolo et al., 2012; Bruez et al., 2014). But these decayed wood zones vary between plants, in terms of aspect (such as black spotting, brown-red wood, sectorial necrosis, white rot), volume, and location in the trunks and arms. Shape and 
colour of necroses can be associated with specific fungi which may be isolated from them (Larignon and Dubos, 1997; Mugnai et al., 1999; Calzarano and di Marco, 2007; Kuntzmann et al., 2010; Maher et al., 2012). These necroses are often spatially associated with pruning wounds (Galet, 1977; Larignon and Dubos, 1997; Mugnai et al., 1999). This suggests that these areas could be entry points and the altered tissues of the desiccation cones could be more likely to be colonized by fungi, although this has not been proven. In some forest trees, it has been shown that discolouration developing from wounds extends more rapidly in an axial than a radial or tangential direction (Deflorio et al., 2007), and that the pith has a role in the extent of decay from a branch to a trunk. In grapevine, the role of the pith in disseminating fungi has also been questioned (Feliciano and Gubler, 2001; van Niekerk et al., 2011).

Volume of necrosis in vine trunks and arms probably decreases downwards from their tops (Mugnai et al., 1999). This is consistent with the fact that the upper trunks (where the Guyot pruning type has been used) and the arms (for cordon and "gobelet" pruning types) host most pruning wounds, compared to the lower trunks and the grafting points supporting fewer wounds established during the first years of vine life.

Necroses are thus double sources of risk for GTDs. Firstly, they host inner inoculum that is likely to further disseminate inside the trunks and arms, and secondly, they reduce functional sapwood and storage capacity of the trunks. However, not all of necrosis types are likely to impede hydraulic conductivity of grapevines. This probably depends on necrosis localization with respect to the functional sapwood. Ascent of the xylem flux can rely on several annual rings of wood although only the last rings are thought to be functional. The older rings are naturally occluded by tyloses (Fournioux and Adrian, 2011), which is analogous to the heartwood of forest trees. We can thus postulate that necroses affecting the external rings play greater roles on the reduction of the xylem sap flow than the more central stem rings.

This raises questions of the impacts of nonfunctional wood associated with GTDs on conductivity, that need to be documented. It would be useful to assess whether GTD fungi and wood necroses actually impact sap conductivity, and how. In that case, exploring alterations of photosynthesis and carbon metabolism would also be required. Increasing knowledge of xylem functional structure in grapevine, and the possible existence of distinct pathways of xylem sap from roots to leaves, would also be very useful to indicate why FS are sometimes expressed on few shoots or on entire vine cano- pies. These points are being addressed in several recently commenced research initiatives.

\section{Step 3: Outburst of tiger stripe-like foliar symptoms}

Tiger stripe-like FS have been well-described by many authors. Notwithstanding, the so called "tiger stripes" (i.e. interveinal drying or discoloured zones) show a range of variability (Lecomte et al., 2012), depending on cultivar or the age of the symptoms.

Because tiger stripe-like FS appear irregularly on vines that also have perennial necroses and inner pathogen inoculum, additional factors besides pathogens and their induced wood necroses need to be considered to explain symptom occurrence. As GTD pathogens have never been retrieved from host leaves, these factors must be remotely inducible from where they act.

Some studies have been dedicated to characterizing the physiological disturbance that occurs on symptomatic leaves showing esca disease or Botryosphaeria dieback, or on asymptomatic leaves from symptomatic canes, and prior to the outburst of FS (Petit et al., 2006; Christen et al., 2007; Andreini et al., 2009; Letousey et al., 2010; Valtaud et al., 2011). This has been reviewed by Wagschal et al. (2008) and Fontaine et al. (2016). Symptomatic leaves show low rates of photosynthesis induced by stomatal closure, impairment of photosynthetic apparatus, and alteration of chlorophyll pigments. These modifications have also been observed on visually healthy leaves of symptomatic grapevine canes, but not on asymptomatic canes.

Apart from GLSD symptoms on leaves, the "brown stripe" needs to be considered, which was found on $95 \%$ of symptomatic vines by Lecomte et al. (2012). This symptom on a vine is a longitudinal stripe of variable width and a few millimetres thick, affecting the young xylem (visible after removing the bark), directly connected to the shoot affected by FS and extending down the arms and trunk, and sometimes reaching the roots. The stripe appearance is first yellow or orange and then ages to brown. Histological observations showed that the colour is due to vessel occlusion and filling with tyloses and gums (Dubos et al., 2001; Larignon, 2010). The brown stripe is not necessarily located close to necrotic tissues or wounds, but severity of FS are related to the width of the stripe (Lecomte et al., 2012). As Botryosphaeriaceae species are frequently retrieved from these brown stripes (Dubos et al., 2001; Kuntzmann et al., 2010), some French authors have considered the symptom to be typical of Botryosphaeria dieback. Lecomte $e t$ al. (2012), however, reported data showing that the wood brown stripe was generic of esca disease. 
Two hypotheses can account for the outburst of tiger stripe-like FS, based on the reports of Galet (1977), Mugnai et al. (1999), Lecomte et al. (2005), Surico et al. (2006), Pouzoulet et al. (2014), and Gómez et al. (2016). These are: (i) the action of GTD fungus-associated phytotoxic compounds, which disseminate and reach the foliage; and (ii) disturbance of sap flow to the leaves on given xylem pathways altered by fungi. These hypotheses are here respectively termed the "toxins" and the "hydraulic dysfunction" hypotheses.

A third hypothesis has recently emerged, which suggests that FS could be due to annual infections by some fungi through pruning or green wounds. The pathogens then progress into the annual shoots, directly causing local FS (Larignon, 2017). More research is required to develop this hypothesis.

\section{The "toxins" hypothesis}

In the "toxins" hypothesis, tiger stripe-like FS would be provoked by the phytotoxic action of one or several metabolites produced by one or several fungi. The metabolites would be released in the vine sap flow to move up to the leaves. The metabolites could affect leaf functioning following their production (or over-production) by the fungi, or because of a lack of capacity of the host to detoxify them. The inciting factors could be a change in micro-environment conditions eliciting toxin production, or a progression of the fungi across reaction zones to infect previously healthy and functional parts of the wood, or an ineffective cellular response of the leaf tissues to the entering toxins.

Considerable research has been reported examining the hypothesis of secondary metabolites and their potential phytotoxic activity on leaves (Sparapano et al., 2000; Abou-Mansour et al., 2004; Martos et al., 2008; Wagschal et al., 2008; Andolfi et al., 2011; AbouMansour et al., 2015). These studies have been encouraged by the similarity of symptoms resulting when the toxins or fungus culture extracts have been re-injected into vine leaves or shoots, compared to GTD symptoms observed in the field. Some of these toxins have also been retrieved in xylem sap or leaves (Bruno and Sparapano, 2006c; Andolfi et al., 2011).

Visual leaf stripe symptoms may appear after the onset of foliar lesions (Fontaine et al., 2016; MagninRobert et al., 2017), which suggests that the visual symptoms may not be directly caused by the toxin(s) but could be a consequence of an oxidative burst triggered by the toxin(s) up to the leaves (Calzarano and Di Marco, 2018). Foliar applications of a mixture containing calcium, reported to limit plant oxidative stress
(Calzarano et al., 2014), reduce incidence of GLSD foliar symptoms (Calzarano et al., 2014; Calzarano and Di Marco, 2018), supporting this hypothesis.

Several questions remain. It is not known if one or potentially all of these compounds cause symptoms. The threshold concentrations inducing toxicity have not been determined. The interactions with factors determining leaf susceptibility, and the modes of access to sap flow also remain to be outlined.

Fmed alone has sometimes been assumed to be responsible of tiger stripe-like FS (Lafon, 1921), as suggested by positive results from the "curetage" (trunk cleaning) method for reducing FS occurrence (Thibault, 2015; Yobregat and Abidon, 2019; Cholet et al., 2019). This method involves removal of all the spongy white rot off the wood of affected plants, using a small chainsaw trimmer, regardless of the discoloured wood that could remain. As the positive effect of "curetage" has been confirmed in different vineyards, the method could be useful for investigating the role of Fmed in symptom appearance, even even if an effect of "curetage" on reducing inner inoculum, or triggering vine defences, cannot be excluded to explain symptom reduction (Mondello et al., 2019).

\section{The "hydraulic dysfunction" hypothesis}

This hypothesis assumes that typical tiger stripe-like symptoms could be due to impairment of the sap flow to the leaves. Following a progression of the fungi to an apparently functional part of the wood, the associated volume of vessels would no longer be able to drive the sap, whether because of a reaction of the vine occluding vessels, the occurrence of "cavitation" phenomena, or because of both. Cavitation is caused by air bubbles that form and coalesce inside the vessels, leading to embolism (Tyree and Sperry, 1989; Cochard, 2006). This can occur when the ratio between transpiration and xylem flow is too great. It generally occurs at the junctions where resistance to the flow is greatest, particularly in petioles and roots (Lovisolo et al., 2008; Zufferey et al., 2011). The same explanation was used by Yadeta and Thomma (2013) to explain the symptoms caused by some vascular pathogens in forest trees.

Unlike the "toxins" hypothesis, where tiger stripelike symptoms are observed after toxin injection into healthy detached leaves, the "hydraulic dysfunction" hypothesis shows no similarity with tiger stripe-like FS. Tiger-stripe symptoms are not visually or physiologically similar to typical grapevine symptoms of edaphic water stress (Christen et al., 2007; Andreini et al., 2009; Letousey et al., 2010; Fontaine et al., 2016; Reis et al., 
2016). FS can show similarities with symptoms of folletage described by Branas (1974), or to some senescence symptoms in autumn.

The impact of wood necrosis or the presence of wood inhabiting fungi on vine hydraulics have not been intensively studied, except for Pch infections on young plants (Edwards et al., 2007; Fischer and Kassemeyer, 2012) or some measurements of resistance to sap flow (Andreini et al., 2009). Recent research (Bortolami et al., 2019) has advanced this area, and is likely to open new research on the hydraulic dysfunction hypothesis.

Compatibility of the hypotheses with major characteristics of tiger stripe-like FS

Tiger stripe-like symptoms can affect whole or parts of plant canopies. With the cordon spur pruning type, the smallest affected unit is the spur, while with Guyot pruning, it is the cane. The explanation could be that xylem of the vine may be sectored, so that a particular part of the xylem is driving sap from a particular part of roots to a particular part of shoots (Shani et al., 1993). Whatever the explanation, severity of canopy FS probably reflects the number or the extent of xylem vessels which are transporting toxin(s), or which express xylem flow dysfunction.

FS can show different expressions (colours, severity on one leaf, severity on each shoot, with or without leaf abscission). These symptoms could be explained by the nature and the concentration of the toxic compounds in the leaves, which may be related to the types of GTD fungi, and to the intensity of hydraulic disruption, or by a combined action of both. The type and status of leaf tissue showing symptoms could also be involved, depending on cultivar, tissue, age, physiological or nutritional status, or developmental stage. In case of the toxins hypothesis, the volume of foliage that receives the toxic compounds (acting as a dilution factor) should also be considered.

In France, tiger stripe-like FS begin after flowering (sometimes late in July for some regions/cultivars). This could be correlated, as for the toxins hypothesis, to vine phenological stage. Flowering is a period of active growth; inflorescences and young grapes become significant sinks for carbon (Lebon et al., 2008). This can result in poor defences capacities, thereby allowing fungi to overstep reaction zones or vine defences. According to the xylem dysfunction hypothesis, this could correspond to the first intense flush of climatic transpiration demand, contributing to impairment of the xylem.

The two hypotheses also explain fluctuations of FS from year to year. Conditions for production, release and distribution of toxins may be fulfilled in one year but not in that following, due to variation in plant defence responses, microbiota and/or environmental status. Xylem function could also be greater in one growing season than in the next. Increased radial growth of new xylem, reduced progression of fungi in healthy ring of wood, or reduced climatic demand could all affect xylem function.

\section{Step 4: Apoplectic events}

Apoplexy is the longest-known symptom attributable to esca (Larignon, 2016), and is probably the most striking. It involves complete wilting of grapevine canopies, leaves and stems within a few days, generally leading to the death of affected vines (Mugnai et al., 1999). Apoplexy occurs most frequently during hot days in July and August each year following rainy events. Old vines are more prone than younger ones (Surico et al., 2006), although apoplexy symptoms have also been noted recently on young vines (Larignon, 2016). When the trunks of affected plants are sectioned longitudinally, they generally show large amounts of decayed and discoloured wood (Maher et al., 2012), with "spongy" material (due to Fmed decay). Hypothesis most frequently proposed is that the abrupt symptom development results from collapse of entire vine hydraulic system, because of decay and critically poor xylem function. These conditions are detrimental to sap flow when associated with intense climatic demand. Apoplexy is a nonspecific symptom which can occur with several other problems or diseases, including the ultimate stages of decline due to Grapevine fanleaf virus or Syrah decline, 'folletage' symptoms, or to mechanical trunk injuries.

\section{Step 5: Vine death}

Apart from the consequence of apoplexy, death of vines that previously expressed FS is poorly described in the literature. Guérin-Dubrana et al. (2012) showed that vine death is associated with GLSD, because affected plants die if FS have occurred at least once in the last 4 previous years. More recently, Calzarano et al. (2018) showed that the percentage of mortality was higher for vines showing severe symptoms at the first appearance.

Vine death can occur progressively as plant canes, arms or spurs die. Lecomte et al. (2014) mention the death of canes and spurs as indicators of GTDs, in addition to FS. In several countries, death of spurs is also typical of Botryosphaeria dieback (van Niekerk et al., 2006; Úrbez-Torres, 2011). Claverie et al. (2017) observed that FS lead to variable death of spurs, from 0 to $96 \%$, 
depending on the FS severity, year, vine cultivar and the vineyard.

Vines can also decline, reducing growth and yield before dying. Petit et al. (2006) showed that tiger stripelike FS lead to reduced reserve restoration in the canes. Andreini et al. (2013) observed bud break delay on vines that were esca symptomatic the year before, with reduced growth rates in the early season being a consequence of less reserve replenishment the previous year (McArtney and Ferree, 1999; Duchêne et al., 2003). Claverie et al. (2017) also observed delayed spring growth and yield reduction for vines that had shown FS the previous year. These results indicate that FS can alter vine growth parameters, at least the year following the appearance of FS. The extent to which lost 'vigour' contributes to decline and death of vines is yet to be assessed.

A given rate of plant mortality in a vineyard could result from the cumulative effects of apoplexy, death of individual canes and spurs, and decline. As a consequence, FS occurrence and plant mortality in a vineyard are only partially correlated, so information on both is needed to describe particular GTD status.

\section{THE ROLE OF "SOIL-CLIMATE-MANAGEMENT" SYSTEMS, MICROBIOTA AND PLANT MATERIAL AS GTD INFLUENCING FACTORS}

Once the process is sequenced, the factors that may influence the GTDs can be integrated. We have been discussing the relationships of these with each component of the model: wounds, outer and inner inoculum, plant defences and sap conductivity. These factors can be in different categories, including host genotype, climate and soil, microbiota, vine physiology and cropping practices.

\section{Influence of vine physiology}

FS and wood symptoms of esca and Botryosphaeria dieback directly impact on vine physiology by reducing the volume of functional tissues for photosynthesis and carbohydrate storage. Beside these direct effects on vine structure, the host-pathogen relationship could also have consequences for grapevine physiology. Expression of active responses to infection at the plant/pathogen interface, as for release of active defence compounds in wood reaction zones, or detoxification of toxins in leaves, implies that plant defence is a substantial expense for carbon assimilates (Pearce, 1996; Berger et al., 2007; Bolton, 2009). This has been conceptualized on plants other than grapevine, especially for pathogens that attack the source organs (leaves) (Berger et al., 2007) and also extensively studied for forest trees and wood pathogens. This assumes trade-offs of tree resources between growth and defences. Optimizing the plant defence pool requires consideration of source/sink relationships at the whole plant level (amount of sources production, competition between sinks). At that point, plant pathology interferes with plant physiology.

Origin and costs of defences

Little information is available on the influence of GTDs on the amount of carbon allocated for plant defences (Bertsch et al., 2013), and on the origin of the carbon used for defences: either $\mathrm{C}$ storage or recently produced photoassimilates, either local storage (in trunks) or distant storage (in roots).

Forest pathology has explored this more deeply, although there is no conclusive consensus. Creation of reaction zones is considered as an investment for host trees, as evidenced by the increased amount of carbon compounds (and derivatives) in the reaction zones, which are surrounded by zones where these compounds are depleted (Christiansen et al., 1987; Viiri et al., 2001; Guérard et al., 2007).

For GTDs, reduced starch is also observed in parenchyma tissues close to the wood infected by fungi (Larignon, 1990; Mugnai et al., 1999; Rudelle et al., 2005; Fontaine et al., 2016) for Eutypa dieback and esca. This indicates that the starch has been used for host defence responses, although direct metabolization of starch by the fungi cannot be excluded.

Some forest tree studies have shown that sources for carbon used for induced defences are primarily from local storage, and if they are required, photosynthates from the leaves translocate to the infection sites (Guérard et al., 2007; Goodsman et al., 2013). Similarly, trees with depleted C storage show increased susceptibility to some pathogens (Wargo, 1996).

These results underline the possible role of $\mathrm{C}$ storage, that, beside ensuring good renewal of the vegetation each spring, may be important in pathogen attack. Reserve allocation in grapevine is commonly assumed to be passively restored every year, from $\mathrm{C}$ excess that is unused for growth of shoots and fruit. Recent studies on trees have reported that, in some cases (tapping of rubber trees or after wounding and attack by pathogens), C storage could be an active sink (Silpi et al., 2007; Chantuma et al., 2009; Goodsman et al., 2013). Identifying energy expensive $\mathrm{C}$ sinks for plant defences suggests the need for study of allocation and partitioning of $\mathrm{C}$ within vines infected by GTD pathogens. 


\section{Competition between sinks}

Different models account for allocation of carbon among organs in plants (Lacointe, 2000), and models based on source/sink relationships are the most commonly referred to in grapevine. Traditional source/sink relationships in grapevine, such as those summarized by Champagnol (1984), assume that the compounds produced by the source organs are allocated to the sinks with priority levels depending on the phenological stages of vine development. Photoassimilates are first used locally by leaves, for respiration and growth, and are then exported to the other sinks depending on their sink strength. Sinks are, firstly, shoot apices, then young berries during their active growth, and then berries and perennial organs (trunks and roots) after cessation of shoot growth. Additional research on grapevine has also reported and assessed $\mathrm{C}$ partitioning patterns among organs (Castelan Estrada, 2001; Bates et al., 2002; Grechi et al., 2007).

Defences against pathogens are generally not explicitly mentioned as sinks, with these responses being commonly aggregated by physiologists with respiration and maintenance costs. In forest trees, it has been demonstrated that following a pathogen attack, the infected host organs become important sinks for C, either for wood (Goodsman et al., 2013) or for infected leaves (that were previously source organs) (Berger et al., 2007). Berger et al. (2007) reported that sink strength can be indicated from cell wall invertase activity. In grapevine canes inoculated with Pmi (lignified internodes), upregulation of a gene coding for a cell wall invertase has been recorded soon (48 h) after infection (Pierron, 2015).

As "sink strength" varies during each year, the $\mathrm{C}$ allocation to defence responses can show different seasonal trends. In forest trees, development of reaction zones is considered to be a dynamic process that can be overcome by pathogens and re-built (Schwarze and Baum, 2000). Host trunks therefore exhibit alternate phases of breakout and new compartmentalization (Christiansen et al., 1987; Pearce, 1996). This dynamic process can be explained by successive greater and lesser amounts of $\mathrm{C}$ allocated to the maintenance of reaction zones. For GTDs, seasonality is also suggested by the variation of host susceptibility depending on phenological stage: Spagnolo et al. (2014a and 2017) observed that flowering was the most susceptible stage to inoculations by two Botryosphaeriaceae species, compared to the earlier Baggiolini stage $G$ (ten leaves separated) and veraison. They suggested a shift in $\mathrm{C}$ allocation rules at flowering that led to reduced $\mathrm{C}$ dedicated to defences. Similarly, tiger stripe-like FS can appear several times on each plant between June and September (Claverie,
2015). The extent to which these successive FS outbursts are due to different amounts of $\mathrm{C}$ allocation to defence, in combination with variations in microbiota ecology or microenvironmental conditions, remains to be studied.

Sources are regulated by stress

Sources are also influenced by environmental stresses, such as drought or nitrogen shortage, in nonlinear ways described by McDowell (2011) and Christiansen et al. (1987). Conceptual models exist to display the effects of resource availability on whole plant metabolism, especially the allocation between primary and secondary metabolisms (for review see Stamp (2003)). Free of water or nitrogen stress, assimilates are dedicated to growth (primary metabolism), resulting in small amounts for defences. When resource availability reduces, growth slows before photosynthesis (Pellegrino et al., 2006), and excess $\mathrm{C}$ is allocated to secondary metabolites such as phenolics. Under prolonged drought, photosynthesis is altered so less $\mathrm{C}$ is available for defences. This is why drought is frequently considered as a predisposing factor for forest tree declines (Desprez-Loustau et al., 2006; Piou et al., 2006), even where it is unclear whether drought acts on defences allocation or on tissues composition and attractiveness for pathogens.

This model is consistent with some observations of grapevine (van Niekerk et al., 2011; Amponsah et al., 2014) and other plants (Schoeneweiss, 1981), showing that, following stem inoculations by Botryosphaeriaceae, the lengths of the wood lesions are increased when predisposed by drought. It is also well-known that tiger stripe-like FS are favoured in fertile soils and vigorous host growth situations (Destrac-Irvine et al., 2007). This apparent contradiction with the previous observations can be explained in that those vineyards show intensive growth and production, which can be deleterious to the secondary metabolism, including defence. In this case, shoot apex and leaf sink strength would be too significant to leave enough $\mathrm{C}$ for defence mechanisms. This is only one possible explanation. Others could be that wood composition is more favourable for nutrition of one or several fungi (Calzarano et al., 2009), or for toxin production (related to FS emergence). Large numbers of shoots and canes pruned in winter could also act as many entry points for the fungi or sources of dead wood. Combined with low overall defences, this may lead to insufficiently protected reaction zones, as hypothesized for forest trees during severe attacks by bark beetles (Christiansen et al., 1987).

These two examples of possible nonlinear stress effects on source/sink relationships emphasize the 
importance of first, identification of which stress factor promotes either wood necrosis, FS outburst or both, as reviewed by Songy et al. (2019), and second, to specify drought or vigour intensities or consequences on grapevines, in order to give objective determination of the amounts of stress on vine $\mathrm{C}$ metabolism. The specific reactions and interactions to stress of all GTD pathogens of the complex must also be considered.

Combining the ecological defence/growth approach (as characterized in trees) and physiological source/ sink allocation rules between organs would be of great importance for GTDs and even for grapevine pathology. It could help assess respective defence, biomass production and reserve replenishment costs and propose cultural practices to define trade-offs between the three factors.

Management and environmental factors related to vine physiology

Grapevine physiology (especially C production and allocations) is determined by the environment, genotype, and crop management practices. Climate (temperature, light, rainfall) is a key factor in vegetative growth, bunch development and phenology, and, therefore, $\mathrm{C}$ allocation. Climate and soil also influence water and nitrogen availability, and the water and nitrogen stresses that regulate photosynthesis and carbohydrate production in leaves. Since cropping practices such as irrigation, fertilization, weed control (competition for nitrogen and water) and planting density (competition with neighbouring vines) affect water and nitrogen resources, they also affect vine physiology. Vine rootstock is also important, because of effects on root development and uptake capacity, and effects on scion vigour. Cropping practices, such as de-budding or green harvesting, may influence the sinks (e.g numbers of bunches), and numbers of wounds (see below). Other practices affecting the $\mathrm{C}$ sources could also be involved, including the vine training system, vegetation topping or trimming, and defoliation.

Additional study of grapevine involving physiology or agronomy could improve knowledge of effects of cropping practices on vine $\mathrm{C}$ and nitrogen balance.

Factors influencing the wounds. Numbers and size of wounds are assumed to be important mainly as probable entry points for pathogens. However, wounds could also affect infection success depending on pruning characteristics.

The effects of pruning on production of dead wood, and on the effectiveness of fungus inoculations have been intensively studied in forest trees (Dujesiefken and
Stobbe, 2002; Eisner et al., 2002), and to a lesser extent in fruit trees (Grosclaude, 1993) and grapevine (Cholet et al., 2017). The influencing pruning parameters are branch diameter (compared to that of trunks), angle of branch insertion on trunks which affects pith continuity, and cut angle, especially with respect to collars. On grapevine, old reports noted similar relationships between pruning parameters (number, size and localization of the pruning wounds, and association with cane collars) and production of "desiccated wood" beneath wounds (Lafon, 1921). More recently, studies have focused on good pruning practices, which protect the wood from discolouration and decay, and thus maintain more functional sap flows (Dal et al., 2008; Lecomte et al., 2011; Simonit et al., 2012; Anonymous, 2013; Delorme, 2015).

In grapevine, the next step will be to define pruning characteristics (number, size, disposition of wounds) that impact inner inoculum and conductivity and hydraulics of host plants. This could help unravel the causes of FS outburst, along with the 'xylem dysfunction' hypothesis; but also confirm if resulting dead wood or non-functional vessels are more susceptible to fungal penetration and colonization than sound tissues.

An indirect consequence of wounding effects is indicated by observations from unpruned or minimally pruned grapevines, as well as from mechanical hedging. With these two pruning methods, wounds are mainly localized on young branches, and less at the interface with old wood. Consequently, these pruning methods are expected to give less dead wood and trunk and arm necroses (Lecomte et al., 2015; Travadon et al., 2016). Recent studies suggest that there is less impact of esca and Botryosphaeria dieback on FS and mortality when these pruning methods are used (Dumot, 2019; Lecomte et al., 2019) but these effects require further confirmation.

To reduce the number of wounds produced in winter, de-budding in spring is likely to have negative influence on GTD infections, as described by Morvan et al. (2012). They observed that elimination of excessive shoots in early spring reduced FS occurrence, possibly because this reduces cane number and subsequent wounding that occurs with winter pruning. Further research is required in different situations to confirm these observations.

Climate and soil. As most GTD fungi utilize airborne inoculum, the role of soil on fungus life cycles has not been closely investigated. The hypothesis requires further investigation for fungi such as $\mathrm{Pch}$ and $\mathrm{Pmi}$ (Larignon and Gramaje, 2015). The role of the soil has been considered indirectly, through impacts on grapevine physiology, and especially on vine vigor. The soil 
parameters to be considered are numerous. They especially relate to soil structure, texture and depth, and to fertility (organic matter, microbial status, mycorrhiza). Recent studies on GTDs have emphasized the role of soilborne micro-organisms in plant defence induction, including effects of endophytic rhizobacteria or fungus biocontrol agents (Di Marco and Osti, 2007; Spagnolo et al., 2015; Yacoub et al., 2016).

Climate can influence several steps of GTD development, including conservation and dissemination of outer inoculum, and colonization inside host wood (Fischer and Peighami-Ashnaei, 2019). These aspects as influenced by heat and drought stress, have been reviewed by Songy et al. (2019), particularly the dual effects of both these stresses, and emphasizing the variable consequences when one or a complex of fungi is considered. Growth of fungi has temperature optima, as reported by many authors for Botryosphaeriaceae (van Niekerk et al., 2006; Úrbez-Torres et al., 2014), Pch and Pmi (Valtaud et al., 2009; Pontini et al., 2014) and El (Sosnowski et al., 2011).

Climate may also influence the composition and evolution of the whole microbiota. Bruez et al. (2014) observed evolution of microbiota composition inside healthy grapevine trunk wood during each year. For apoplexy and tiger stripe-like FS outburst, climate affects transpiration flow, which is consistent with both hypotheses (but possibly greater for xylem dysfunction, although possibly also for triggering toxin production (Pontini et al., 2014)).

Several studies have focused on relationships between temperature, rain and FS. Most indicate occurrence of FS is positively correlated to years with high rainfall in spring and summer (Surico et al., 2000; Marchi et al., 2006; Larignon, 2009; Andreini et al., 2014; Calzarano et al., 2018). This association requires further elucidation with gradual assessment, to answer to the following questions: do rainy events act on vine carbon and nitrogen balance and on host defences and host/pathogen relationships? Does climate affect temperature and moisture content of trunks favouring colonization by fungi or evolution of internal trunk microbiota? Does it act on soil water content and induce high levels of transpiration and sap flow?

Genotypic factors. No Vitis species used as rootstocks and no grapevine (Vitis vinifera) cultivars are known to be resistant to GTDs (Bertsch et al., 2013). Genetically controlled abilities to counteract GTDs are most likely tolerance based on combination of host life traits (Péros, 1995).

In grafted vines, the effects of rootstocks on GTDs is indirect, acting through vigour conferred to scions and rootstock rooting capacity. On rootstock mother grape- vines, that are pruned each year, discolouration and decay are observed on trunks (Liminana et al., 2009). But when these genotypes are used as rootstocks, they show fewer lesions than the scions (Mugnai et al., 1999). This is probably due to reduced recurrent wounding when they are located belowground (after grafting and planting) than to less intrinsic susceptibility, since rootstocks have no greater tolerance when inoculated with GTD fungi (Billones-Baaijens et al., 2014; Guan et al., 2016). When rootstocks are compared in field trials for ability to develop FS, they show variable performance (Eskalen et al., 2001; Marchi, 2001; Morvan et al., 2011; Andreini et al., 2014; Murolo and Romanazzi, 2014; Laveau et al., 2015; Dumot, 2019). These results suggest the indirect influences of rootstocks on GTD development through one or several effects on grapevine physiology.

The influence of the host cultivar can be in three actions: (i) direct action on the colonization by fungi; (ii) direct action on the outburst of FS; and (iii) indirect action through grapevine physiology at any stage, from pruning wounds and infections, to hydraulic conductivity, fruit production and leaf/shoot ratio. This is suggested by the different susceptibility rankings of cultivars, based on their FS expression or on their responses to infection (e.g. extent of wood discolouration). Multi-faceted tolerance is also suggested by the combined results of tiger stripe-like FS rate, recurrence, and mortality rates for different cultivars. Cabernet Sauvignon had high rates and recurrence of FS but low mortality, while Chardonnay had high rate of mortality but low amounts of FS (Andreini et al., 2014). This has also been observed for Grenache compared with Cabernet Sauvignon (Claverie, unpublished). This suggests an uncoupling between the causes underlying FS and mortality.

Some distinct factors associated with tolerance to GTDs have been identified. Cultivars show different capacities for production of defence compounds, with more and more rapidly produced defence compounds detected in tolerant than in susceptible genotypes (Martin et al., 2009; Lambert et al., 2013; Spagnolo et al., 2014b). Different wood compositions (e.g lignin) may affect constitutive defence levels. The sizes of xylem vessels could also affect tolerance to GTDs, as it may be more energy expensive to occlude large vessels than small ones (CODIT wall 1). Large vessels could also be more prone to cavitation (Pouzoulet et al., 2014). Compared to rootstock or cultivar, the impact of cultivar clones on expression of esca or Botryosphaeria dieback have been less documented (Chevrier, 2013; Murolo and Romanazzi, 2014; Moret et al., 2019). Results suggest that if a clone effect on GTD expression can be observed at the vineyard scale, no stable effect can be generalized at 
a more global scale, across different seasons or with different changing rootstocks.

Microbiota. Antagonist microorganisms can impact other microbes by competing for niches or nutrients, interfering with toxins or secreting toxic compounds (Compant et al., 2013). They can also stimulate grapevine defences (particularly systemic defences) or enhance host resistance to stress (Mondello et al., 2018).

Several reports highlight absence of correlations of fungal composition between symptomatic and asymptomatic wood (Bruez, 2013; Elena et al., 2019). This can be explained by the multiple conditions and steps that are necessary to trigger FS (e.g particular plant physiological status, or amounts of decayed and discoloured wood required before FS appear). Another explanation may be the dynamic evolution of the vine microbiota (in a time span as little as a year) compared to the generally longlasting process (several years) from infection and colonization to FS emergence.

Nevertheless, the action of antagonistic microorganisms on the populations of fungi associated with GTDs can be assumed. High amounts of GTD fungi and Trichoderma have been found in visually clear wood of 50 -year-old asymptomatic vines, suggesting a microbial balance that may contribute to maintaining the healthy status of these vines (Bruez et al., 2016). It has also been suggested that such a balance between plant host, environment and microbiota could trigger pathogenicity from non-pathogenic endophytes (Úrbez-Torres, 2011), thus emphasizing on the importance of the hostpathogen-environment triangle (Fischer and PeighamiAshnaei, 2019), or even adding it a fourth component, resulting in the pathobiome concept (Brader et al., 2017).

Mondello et al. (2018) reported that 40 bacteria or fungi have been studied as potential biocontrol agents for GTDs. These agents can interfere at different stages in the disease conceptual model. These could affect microbial balance inside grapevine trunks, but also as pruning wound protectants (both in nurseries and vineyards) or defence stimulators (e.g. using Pythium oligandrum; Yacoub et al., 2016). With the increasing demand for environmentally acceptable disease control agents, and the development of molecular technologies to accelerate their selection and assess their efficacy, investigations on exploiting the biocontrol potential of microbiota are important.

Another influencing factor to mention in the scope of microbiota is: if a lot of work has been done to select efficient active ingredients against GTDs associated fungi (Mondello et al., 2018), the chemical control against annual grapevine diseases and pests has also proven to impact the whole grapevine microbiota (Pinto et al., 2014) without being able to know in which way they influence this complex system.

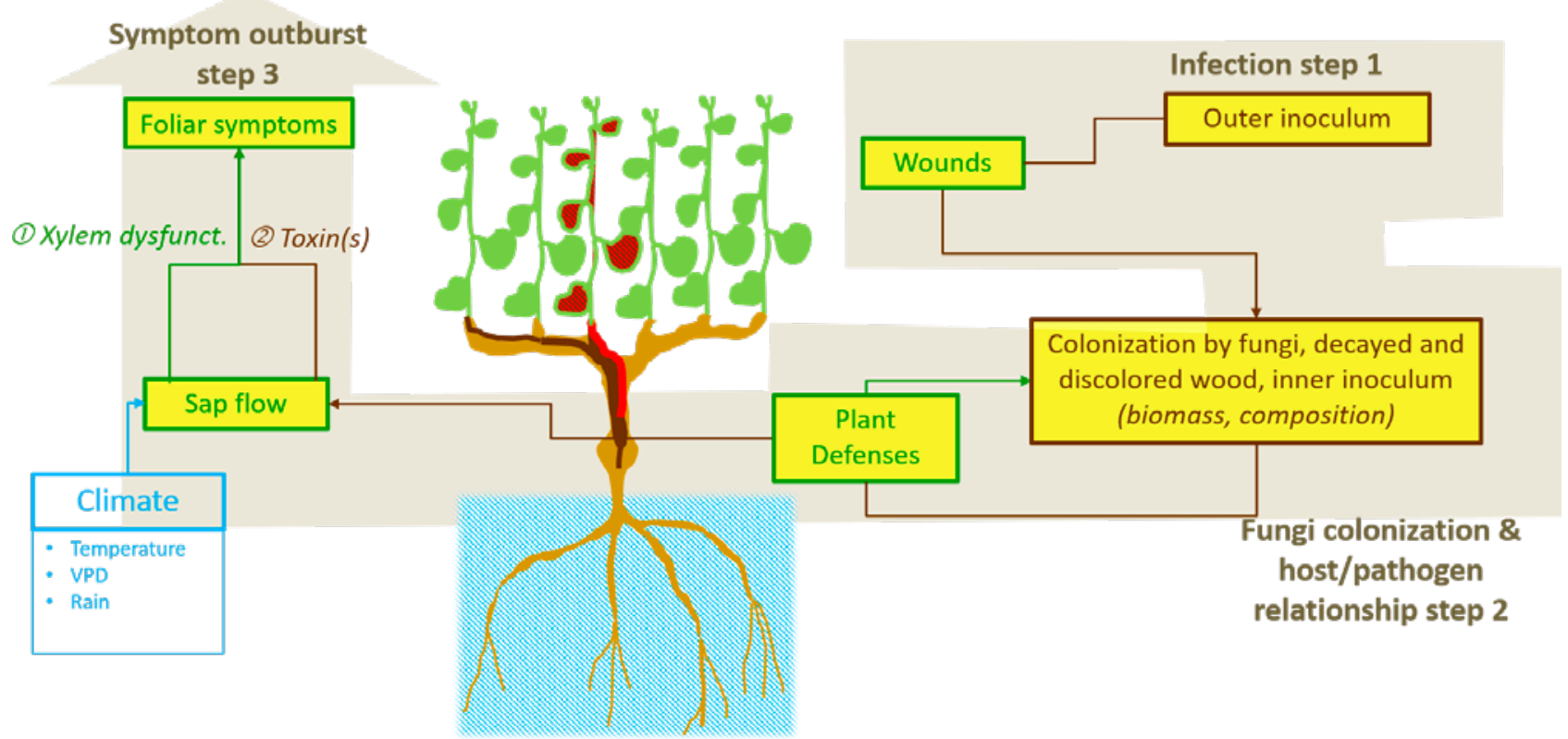

Figure 1. Hypothetical sequence of events leading to grapevine foliar symptom outburst. The process can be divided into three steps that can unfold over several years or occur several times each year and on different parts of each vine. The sequence ends with production of dead, discoloured wood (necrosis) on perennial structures as well as foliar symptoms, leading to grape quantity or quality losses, and to death of parts of, or entire, vines. VPD = vapor pressure deficit. 


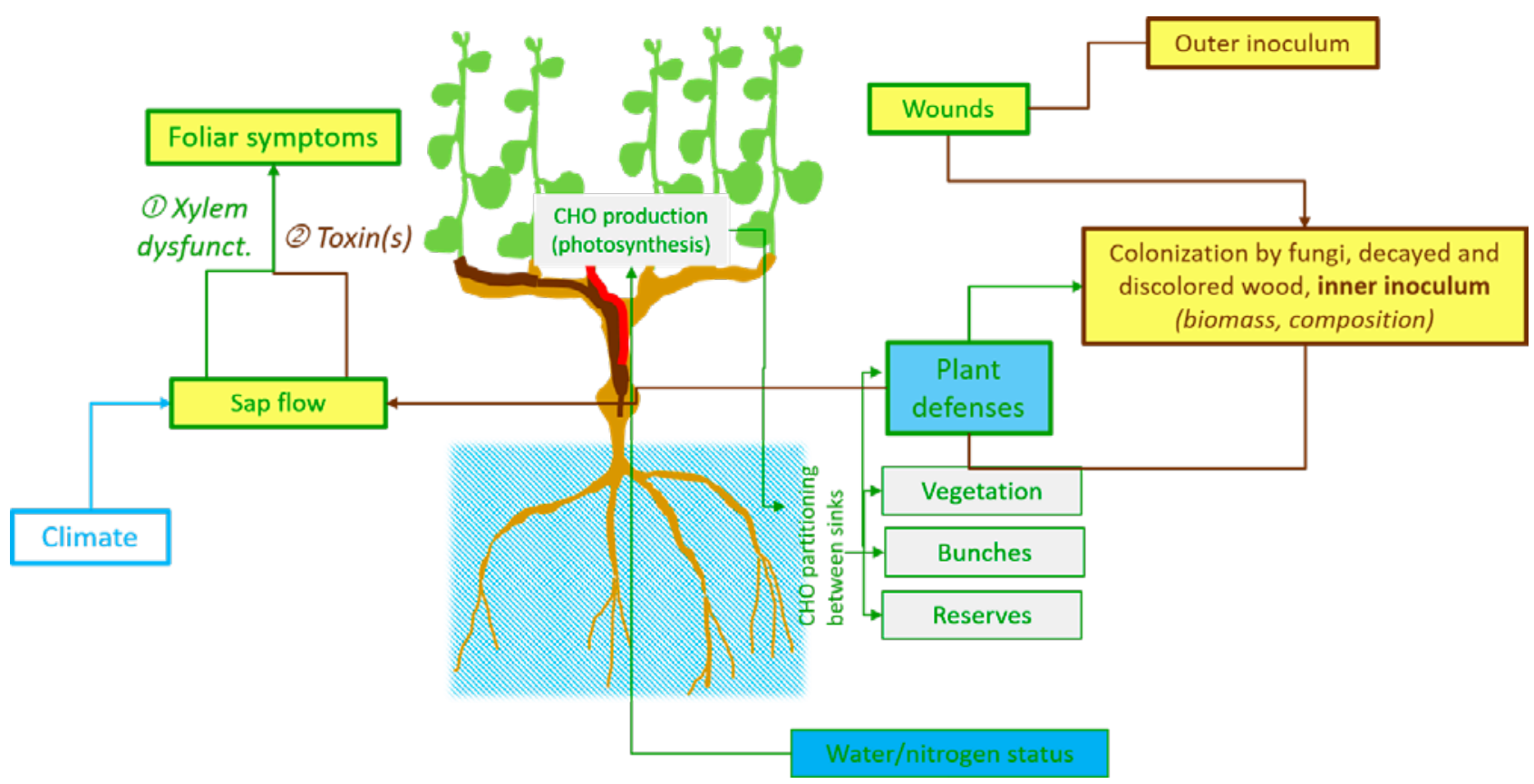

Figure 2. Investment in defences at the host/pathogen interface and probable implication of whole plant physiology: when pathology meets physiology. If foliar and wood symptoms cause direct losses for grapevine functioning, defence allocation will also be a probable expensive investment for affected vines, at the host/pathogen interfaces. This expense could be considered as a sink for $\mathrm{C}$ assimilates, like shoot growth, grape production or reserve replenishment. The role of trunk reserves (starch and derivatives) in supplying energy for local defences in the wood is possible, but still to be investigated. Implication of vine balance in optimizing defence allocation would be an interesting direction for future research. $\mathrm{CHO}=$ Carbon, Hydrogen, Oxygen ( $\mathrm{C}$ assimilates)

\section{CONCLUSIONS AND PERSPECTIVE}

This review aimed to integrate, with a systemic approach, the hypothetical or demonstrated processes, dysfunctions and stages explaining the occurrence of FS and death of grapevines affected by esca and Botryosphaeria dieback. Available literature on these diseases has been reviewed, as well as other relevant topics on grapevine and on forest trees. The main hypotheses currently proposed by researchers and advisors for these diseases has been summarized. Building a sequence of steps in the progression of GTDs helped to develop assumptions to elucidate their complex etiology, and brought knowledge from several disciplines into a broad perspective.

A conceptual model is proposed, based on Figures 1,2 and 3. Figure 1 summarizes the three distinct steps that lead to tiger stripe-like FS, Figure 2 presents the possible connections of GTDs with vine physiology at the host/pathogen interface, and Figure 3 summarizes the major factors contributing to slow down or acceleration of the processes added on a prior "baseline". This system is a grapevine-microbiota association within a set of environmental factors according to specific conditions. These conditions can be either positive for the pathogenic fungi, or deleterious to host grapevines. They can lead to the progression of the fungi in host wood, inducing various amounts of dead or non-functional wood, and be sources of inner inoculum for further colonization. Both can culminate in expression of FS, either through direct phytotoxic effects or indirect disruption of the sap conductive systems. This unfavourable situation for grapevines causes yield and quality losses, and death of parts of, or entire, vine wood structures (branches or trunks), mainly through direct FS impact. Some indirect drawbacks can also occur, through alteration of grapevine physiological functioning, including photosynthesis efficiency, potential reserve replenishment, enhanced costs for defences or modifications in source/sink relationships. Together, these trigger the negative grapevine decline process.

From the knowledge integrated in this review, we propose a sequence of events taking place to explain FS outburst. Since this analysis remains "qualitative", it is not possible to "rank" the importance of the events for the probability or rapidity of FS occurrence. The respective contributions of infection, colonization, host defences and FS outburst putative causes to avoidance or reduction of FS and mortality are unable to be assessed. Nevertheless, this knowledge is necessary before test- 


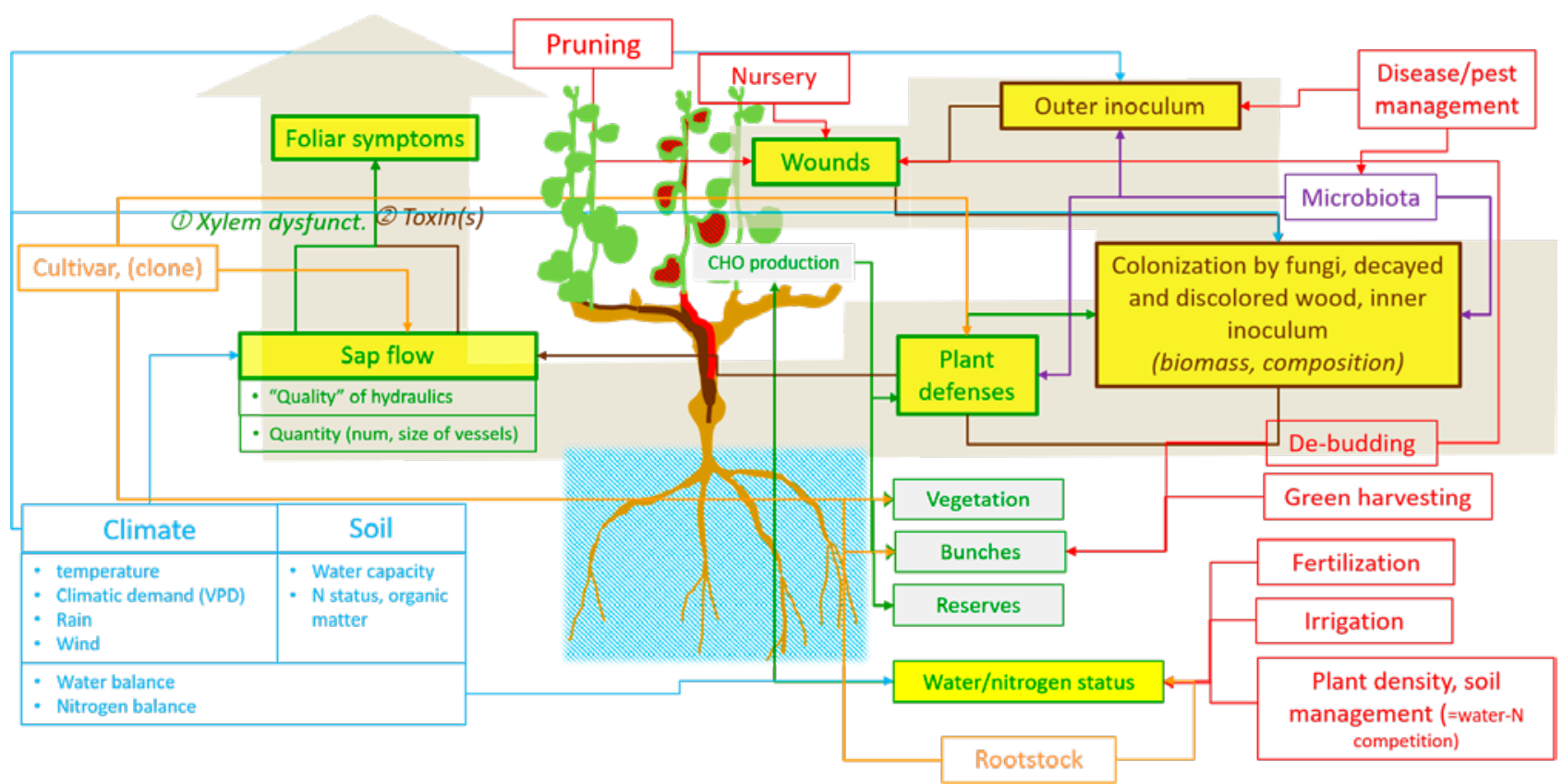

Figure 3. Conceptual model of GTDs based on the hypothetical sequence of events and adding major drivers of the system. GTD-associated fungi are part of the microbiota and account for outer and inner inoculum. They enter vines through wounds, at many possible stages during the vine lifetimes, co-existing and interacting at the reaction zones. Because they are wood inhabiting fungi that alter wood (where storage and sap flow take place), because defences are needed, and because FS can alter vine physiology, global source/sink relationships need to be considered as indirect drivers in this approach. Grapevine/fungi relationships are modulated by microbiota and environmental conditions during each growing season and during vine lifetimes. These multiple combinations result in occasional outbursts of foliar symptoms contributing to vine decline and death. The modulating factors belong to different categories: relations inside the microbiota (indicate in purple), climate and soil (blue), scion and rootstock genotypes (orange), cultural practices (red), that impact wound production and infection or grapevine physiology. A single factor can impact different parts of the sequence, aggravating the complexity. This conceptual model needs to be validated. $\mathrm{N}=$ Nitrogen, $\mathrm{VPD}$ = vapor pressure deficit, $\mathrm{CHO}=$ Carbon, Hydrogen, Oxygen (C assimilates).

ing solutions to avoid or limit GTDs. Would it be more relevant to improve defence mechanisms or to reduce the amount of infection points to limit FS occurrence? Would it be sufficient to associate a tolerant cultivar with few pruning wounds to control GTDs in most climates of the world? Are pathogenic fungi the most influential factors in the model, or is vine physiology, generated by combinations of unfavourable cropping practices, more important? How efficient would it be to fulfill requirements to maintain particular favourable equilibria of vine microbiota? How will the system evolve in the context of ongoing global climate change? Some of these questions could be addressed by research in factorial vineyard experiments and long-term monitoring, which is probably difficult establish. As vine growers are subject to technical and economic constraints, they are unlikely to explore and implement all possible approaches to GTD management. Knowledge upon these methods will be crucial for profitable grapevine production.

As the proposed conceptual model attempts to identify each step in FS development, approach could also be used to build a diagnostic tool in real situations, for example to suggest the GTD weakness points for a given vineyard, or to elaborate vineyard monitoring systems leading to low FS and damage. For that, it will be important to have practical indicators and tools describing the system status. This could include a real-time indicator of grapevine defence status, a practical tool to assess qualitative and quantitative outer inoculum patterns in a vineyard, a marker of grapevine hydraulic efficiency, and a non-destructive indicator of the amount of decayed or non-functional wood in vine trunks.

\section{ACKNOWLEDGEMENTS}

The authors thank gratefully the experts interviewed who shared their vision, submitted literature or gave opinions on the approach outlined in this review. These people include: J.P. Goutouly, UMR EGFV, INRA Bordeaux ; J.P. Péros, UMR AGAP, INRA Supagro Montpellier ; P. Lecomte, UMR SAVE, INRA Bordeaux ; L. Gué- 
rin-Dubrana, UMR SAVE, INRA Bordeaux ; C. Bertsch, Université de Haute-Alsace ; F. Fontaine, A. Spagnolo, Université de Reims Champagne-Ardenne ; P. Larignon, IFV ; Patrice Rey, UMR SAVE, INRA Bordeaux ; J.C. Domec, Bordeaux Sciences Agro ; V. Dumot, Station Viticole du BNIC; M. Barthe, CIVB ; L. Le Cunff et C. Moisy, IFV ; O. Jacquet, Chambre d'agriculture de Vaucluse ; G. Delorme, Chambre d'agriculture du Jura ; $\mathrm{M}$. Badier, Chambre d'agriculture du Loir-et-Cher ; F. Dal, SICAVAC ; J.C. Payan, IFV ; G. Morvan, C. Grosjean, Chambre d'agriculture de l'Yonne et Chambre Régionale de Bourgogne ; B. Broquedis, Chambre d'agriculture du Gard ; H. Cochard, A. Lacointe, UMR PIAF, INRA Clermont-Ferrand ; J.Y. Cahurel, IFV; M. Coarer, IFV.

We also thank the experts solicited for overviews during the COST meeting in Cognac in June 2015: S. di Marco, CNR IBE, Bologna, Italy ; M. Sosnowski, SARDI, Australia; J.R. Urbez Torres, Pacific Agri-Food Research Center, British Columbia, Canada ; C. Rego, Instituto Superior de Agronomia, Lisboa, Portugal; D. Ezra, Volcani center, Bet-Dagan, Israël; V. Hoffsteter, Agroscope Changins, Switzerland; J. Armengol, Instituto Agroforestal Mediterráneo, Valencia, Spain; E. Karaffa, Z. Bihari, Institute of Food Science, University of Debrecen, Hungary.

The authors also acknowledge the V1303 CASDAR project and its leader C. Chevrier for supporting this study, and the CASDAR and the Ministère de l'Alimentation, de l'Agriculture et de la Forêt for funding.

\section{LITERATURE CITED}

Abou-Mansour E., Couché E., Tabacchi R., 2004. Do fungal naphthalenones have a role in the development of esca symptoms? Phytopathologia Mediterranea 43: 75-82.

Abou-Mansour E., Débieux J.L., Ramírez-Suero M., Bénard-Gellon M., Magnin-Robert M., ... Larignon P., 2015. Phytotoxic metabolites from Neofusicoccum parvum, a pathogen of Botryosphaeria dieback of grapevine. Phytochemistry 115: 207-215.

Amalfitano C., Evidente A., Surico G., Tegli S., Bertelli E., Mugnai L., 2000. Phenols and stilbene polyphenols in the wood of esca-diseased grapevine. Phytopathologia Mediterranea 39: 178-183.

Amponsah N.T., Jones E.E., Ridgway H.J., Jaspers V.M., 2014. Factors affecting Neofusicoccum luteum infection and disease progression in grapevines. Australasian Plant Pathology 43: 547-556.

Andolfi A., Mugnai L., Luque J., Surico G., Cimmino A., Evidente A., 2011. Phytotoxins produced by fungi associated with grapevine trunk diseases. Toxins (Basel) 3: 1569-1605.

Andreini L., Caruso G., Bertolla C., Scalabrelli G., Viti R., Gucci R., 2009. Gas exchange, stem water potential and xylem flux on some grapevine cultivars affected by esca disease. South African Journal of Enology and Viticulture 30: 142-147.

Andreini L., Guarino L., Viti R., Scalabrelli G., 2013. Evaluation of the effect of esca disease on bud break in Vitis vinifera L.: Possible relationship between cultivars and rootstocks. Vitis-Journal of Grapevine Research 52: 33.

Andreini L., Cardelli R., Bartolini S., Scalabrelli G., Viti R., 2014. Esca symptoms appearance in" Vitis vinifera" L.: influence of climate, pedo-climatic conditions and rootstock/cultivar combination. Vitis: Journal of Grapevine Research 53: 33-38.

Anonymous, 2013. Manuel des pratiques viticoles contre les maladies $d u$ bois. Sicavac BIVC.

Aroca Á., Gramaje D., Armengol J., García-Jiménez J., Raposo R., 2010. Evaluation of the grapevine nursery propagation process as a source of Phaeoacremonium spp. and Phaeomoniella chlamydospora and occurrence of trunk disease pathogens in rootstock mother vines in Spain. European Journal of Plant Pathology 126: 165-174.

Bates T.R., Dunst R.M., Joy P., 2002. Seasonal dry matter, starch, and nutrient distribution in 'Concord' grapevine roots. HortScience 37: 313-316.

Baum S., Sieber T.N., Schwarze F.W., Fink S., 2003. Latent infections of Fomes fomentarius in the xylem of European beech (Fagus sylvatica). Mycological Progress 2: 141-148.

Berger S., Sinha A.K., Roitsch T., 2007. Plant physiology meets phytopathology: plant primary metabolism and plant-pathogen interactions. Journal of Experimental Botany 58: 4019-4026.

Bertsch C., Ramírez-Suero M., Magnin-Robert M., Larignon P., Chong J., ... Fontaine F., 2013. Grapevine trunk diseases: complex and still poorly understood. Plant Pathology 62: 243-265.

Billones-Baaijens R., Jones E.E., Ridgway H.J., Jaspers M.V., 2014. Susceptiblity of common rootstock and scion varieties of grapevines to Botryosphaeriaceae species. Australasian Plant Pathology 43: 25-31.

Boddy L., Rayner A.D.M., 1983. Origins of decay in living deciduous trees: the role of moisture content and a re-appraisal of the expanded concept of tree decay. New Phytologist 94: 623-641.

Bolton M.D., 2009. Primary metabolism and plant defence-fuel for the fire. Molecular Plant-microbe Interactions 22: 487-497. 
Bortolami G., Gambetta G.A., Delzon S., Lamarque L.J., Pouzoulet J., ... Delmas C., 2019. Exploring the Hydraulic Failure Hypothesis of Esca Leaf Symptom Formation. Plant Physiology 181: 1163-1174.

Brader G., Compant S., Vescio K., Mitter B., Trognitz F.,... Sessitsch A., 2017. Ecology and genomic insights into plant-pathogenic and plant-nonpathogenic endophytes. Annual Review of Phytopathology 55: 61-83.

Branas J., 1974. Folletage. In Viticulture (ED. Dehan), Montpellier, 606-611.

Bruez E., 2013. Etude comparative des communautés fongiques et bactériennes colonisant le bois de ceps de vigne ayant exprimé ou non des symptômes d'esca, $\mathrm{PhD}$ Thesis, University of Bordeaux II, $258 \mathrm{pp}$.

Bruez E., Lecomte P., Grosman J., Doublet B., Bertsch C., ... Rey P., 2013. Overview of grapevine trunk diseases in France in the 2000s. Phytopathologia Mediterranea 52: 262-275.

Bruez E., Vallance J., Gerbore J., Lecomte P., Da Costa J. P., ... Rey P., 2014. Analyses of the temporal dynamics of fungal communities colonizing the healthy wood tissues of esca leaf-symptomatic and asymptomatic vines. PLoS One 9(5).

Bruez E., Baumgartner K., Bastien S., Travadon R., Guérin-Dubrana L., ... Rey P., 2016. Various fungal communities colonise the functional wood tissues of old grapevines externally free from grapevine trunk disease symptoms. Australian Journal of Grape and Wine Research 22: 288-295.

Bruno G., Sparapano L., 2006a. Effects of three esca-associated fungi on Vitis vinifera L.: III. Enzymes produced by the pathogens and their role in fungus-toplant or in fungus-to-fungus interactions. Physiological and Molecular Plant Pathology 69: 182-194.

Bruno G., Sparapano L., 2006b. Effects of three esca-associated fungi on Vitis vinifera L.: I Characterization of secondary metabolites in culture media and host responses to the pathogens in calli. Physiological and Molecular Plant Pathology 69: 209-223.

Bruno G., Sparapano L., 2006c. Effects of three esca-associated fungi on Vitis vinifera L.: II. Characterization of biomolecules in xylem sap and leaves of healthy and diseased vines. Physiological and Molecular Plant Pathology 69: 195-208.

Calzarano F., Di Marco S., 2007. Wood discoloration and decay in grapevines with esca proper and their relationship with foliar symptoms. Phytopathologia Mediterranea 46: 96-101.

Calzarano F., Di Marco S., 2018. Further evidence that calcium, magnesium and seaweed mixtures reduce grapevine leaf stripe symptoms and increase grape yields. Phytopathologia Mediterranea 57: 459-471.
Calzarano F., Seghetti L., Del Carlo M., Cichelli A., 2004. Effect of esca on the quality of berries, musts and wines. Phytopathologia Mediterranea 43: 125-135.

Calzarano F., Amalfitano C., Seghetti L., Cozzolino V., 2009. Nutritional status of vines affected with esca proper. Phytopathologia Mediterranea 48: 20-31.

Calzarano F., Di Marco S., D’Agostino V., Schiff S., Mugnai L., 2014. Grapevine leaf stripe disease symptoms (esca complex) are reduced by a nutrients and seaweed mixture. Phytopathologia Mediterranea 53: 543-558.

Calzarano F., Osti F., Baranek M., Di Marco S., 2018. Rainfall and temperature influence expression of foliar symptoms of grapevine leaf stripe disease (esca complex) in vineyards. Phytopathologia Mediterranea 57: 488-505.

Castelan Estrada M., 2001. Répartition de la biomasse chez Vitis vinifera $L$.; rendement de conversion $d u$ rayonnement solaire global et coûts énergétiques. $\mathrm{PhD}$ Thesis, Paris, Institut national d'agronomie de Paris Grignon, Paris, 132 pp.

Champagnol F., 1984. Elements de physiologie de la vigne et de viticulture generale, $351 \mathrm{pp}$.

Chantuma P., Lacointe A., KasemsapP., Thanisawanyangkura S., Gohet E., ....Thaler P., 2009. Carbohydrate storage in wood and bark of rubber trees submitted to different level of $\mathrm{C}$ demand induced by latex tapping. Tree Physiology 29: 1021.

Chevrier C., 2013. Etude de l'impact des choix culturaux des viticulteurs sur le développement des maladies $d u$ bois. Paper presented at the Les maladies du Bois de la Vigne- Réunion du groupe national Maladies du Bois de la Vigne, Angers. 19\&20/03/2013, 31-35.

Chiarappa L., 2000. Esca (black measles) of grapevine. An overview. Phytopathologia Mediterranea 39: 11-15.

Cholet C., Martignon T., Giudici M., Simonit M., Geny L., 2017. Vigne: pourquoi tailler moins ras aide à freiner l'esca. Phytoma 702: 38-41.

Cholet C., Bruez E., Lecomte P., Rey P., Boury T., .... Geny-Denis L., 2019. Intérêt du curetage dans la lutte contre l'esca. Phytoma 728: 24-27.

Christen D., Schönmann S., Jermini M., Strasser R.J., Défago G., 2007. Characterization and early detection of grapevine (Vitis vinifera) stress responses to esca disease by in situ chlorophyll fluorescence and comparison with drought stress. Environmental and Experimental Botany 60: 504-514.

Christiansen E., Waring R.H., Berryman A.A., 1987. Resistance of conifers to bark beetle attack: searching for general relationships. Forest Ecology and Management 22: 89-106. 
Claverie M., 2015. Suivi symptômes et fonctionnement $d u$ cep. Paper presented at the Journées Nationales Maladies du Bois, Colmar.

Claverie M., Jouandou N., Jacquet O., Richy D., 2017. Foliar symptoms of GTDs are associated with decline of the vines. Phytopathologia Mediteranea 56: 533.

Cochard H., 2006. Cavitation in trees. Comptes Rendus Physique 7: 1018-1026.

Compant S., Brader G., Muzammil S., Sessitsch A., Lebrihi A., Mathieu F., 2013. Use of beneficial bacteria and their secondary metabolites to control grapevine pathogen diseases. BioControl 58: 435-455.

Cottral E., Pascoe I.G., Edwards J., Jaudzems G., Taylor P.A., 2004. Host-pathogen interaction of Phaeomoniella chlamydospora, causal organisms of Petri disease, in grapevine tissue. Phytopathologia Mediterranea 43: 150.

Dal F., Bricaud E., Chagnon L., Daulny B., 2008. Relation entre qualite de la taille et deperissement des vignes. Exemple de l'esca. Le Progrès Agricole et Viticole 125: 602-608.

Davy A., Larignon P., Vergnes M., Cestaret S., 2011. Study of the responsiveness of wounds generated during the vegetative period regarding two pioneer esca fungi. Lacanau, Gironde, France, 3-5 octobre 2011.

De La Fuente M., Fontaine F., Gramaje D., Armengol J., Smart R., ... Corio-Costet M.-F., 2016. Grapevine trunk diseases. A review. In OIV (Ed.), 1st edition (pp. 24). Paris, France: International Organisation of Vine and Wine (OIV).

Deflorio G., Barry K.M., Johnson C., Mohammed C. L., 2007. The influence of wound location on decay extent in plantation-grown Eucalyptus globulus and Eucalyptus nitens. Forest Ecology and Management 242: 353-362.

del Rio J., Gonzalez A., Ortuño A., Botia J.M., Fuster M.D., ... Frias V., 2001. Tylose Formation and Changes in Phenolic Compounds of Grape Roots Infected with "Phaeomoniella chlamydospora» and "Phaeoacremonium» Species. Phytopathologia Mediterranea 40: 394-399.

del Río J., Gómez P., Baidez A., Fuster M.D., Ortuno A., Frías V., 2004. Phenolic compounds have a role in the defence mechanism protecting grapevine against the fungi involved in Petri disease. Phytopathologia Mediterranea 43: 87-94.

Delorme G., 2015. Influence du fonctionnement interne $d u$ cep sur l'expression des symptômes Esca/BDA. Paper presented at the Les maladies du Bois de la vigne, Colmar, 17 et 18/11/15, 53-54.

Desprez-Loustau M.-L., Marçais B., Nageleisen L.-M., Piou D., Vannini A., 2006. Interactive effects of drought and pathogens in forest trees. Annals of Forest Science 63: 597-612.

Destrac-Irvine A., Goutouly J.P., Laveau C., GuerinDubrana L., 2007. Lécophysiologie de la vigne Mieux comprendre les maladies de dépérissement. L'Union Girondine des Vins de Bordeaux 1035: 28-32.

Di Marco S., Osti F., Mazzullo A., Cesari A., 2001. How iron could be involved in esca fungi development. Phytopathologia Mediterranea 40: S449-S452.

Di Marco S., Osti F., 2007. Applications of Trichoderma to prevent Phaeomoniella chlamydospora infections in organic nurseries. Phytopathologia Mediterranea 46: 73-83.

Dubos B., Cere L., Larignon P., Fulchic R., 2001. Observation on black dead arm in French vineyards. Phytopathologia Mediterranea 40: 336-342.

Duchêne E., Monamy C., Langellier F., Jaegli N., Salber R., ... Panigai L., 2003. Effects of the ripening conditions in the vineyard on growth and yield components in the following season. Journal International des Sciences de la Vigne et du Vin 37: 103-116.

Dujesiefken D., Stobbe H., 2002. The Hamburg Tree Pruning System-A framework for pruning of individual trees. Urban Forestry \& Urban Greening 1: 75-82.

Dumot V., 2019. Effets et limites des pratiques viticoles sur les maladies $d u$ bois. Paper presented at the 4èmes Assises des Vins du Sud-Ouest, 24/01/2019, 61-63.

Edwards J., Pascoe I.G., Salib S., 2007. Impairment of grapevine xylem function by Phaeomoniella chlamydospora infection is due to more than physical blockage of vessels with goo. Phytopathologia Mediterranea 46: 87-90.

Eisner N.J., Gilman E.F., Grabosky J.C., 2002. Branch morphology impacts compartmentalization of pruning wounds. Journal of Arboriculture 28: 99-105.

Elena G., Bruez E., Rey P., Luque J., 2019. Microbiota of grapevine woody tissues with or without esca-foliar symptoms in northeast Spain. Phytopathologia Mediterranea 57: 425-438.

Eskalen A., Gubler W.D., Khan A., 2001. Rootstock Susceptibility to "Phaeomoniella chlamydospora» and "Phaeoacremonium»spp. Phytopathologia Mediterranea 40: 433-438.

Feliciano A.J., Gubler W.D., 2001. Histological Investigations on Infection of Grape Roots and Shoots by "Phaeoacremonium»spp. Phytopathologia Mediterranea 40: 387-393.

Feliciano A.J., Eskalen A., Gubler W.D., 2004. Differential susceptibility of three grapevine cultivars to Phaeomoniella chlamydospora in California. Phytopathologia Mediterranea 43: 66-69. 
Fischer M., Kassemeyer H.H., 2012. Water regime and its possible impact on expression of Esca symptoms in Vitis vinifera: growth characters and symptoms in the greenhouse after artificial infection with Phaeomoniella chlamydospora. Vitis-Journal of Grapevine Research 51: 129.

Fischer M., Peighami-Ashnaei S., 2019. Grapevine, esca complex, and environment: the disease triangle. Phytopathologia Mediterranea 58: 17-37.

Fleurat-Lessard P., Luini E., Berjeaud J.M., Roblin G., 2010. Diagnosis of grapevine esca disease by immunological detection of Phaeomoniella chlamydospora. Australian Journal of Grape and Wine Research 16: 455-463.

Fleurat-Lessard P., Luini E., Berjeaud J.-M., Roblin G., 2014. Immunological detection of Phaeoacremonium aleophilum, a fungal pathogen found in esca disease. European Journal of Plant Pathology 139: 137-150.

Fontaine F., Pinto C., Vallet J., Clément C., Gomes A.C., Spagnolo A., 2016. The effects of grapevine trunk diseases (GTDs) on vine physiology. European Journal of Plant Pathology 144: 707-721.

Fournioux J.C., Adrian M., 2011. Morphologie et anatomie de la vigne, Edition Féret, $144 \mathrm{pp}$.

Galet P., 1977. Apoplexie. In Les Maladies et les Parasites de la Vigne Tome I. Les Maladies dues à des Végétaux. Montpellier, France: Imprimerie du Paysan du Midi, 409-430.

Gómez P., Báidez A.G., Ortuño A., Del Río J.A., 2016. Grapevine xylem response to fungi involved in trunk diseases. Annals of Applied Biology 169: 116-124.

Goodsman D.W., Lusebrink I., Landhäusser S.M., Erbilgin N., Lieffers V.J., 2013. Variation in carbon availability, defence chemistry and susceptibility to fungal invasion along the stems of mature trees. New Phytologist 197: 586-594.

Gramaje D., Armengol J., 2011. Fungal trunk pathogens in the grapevine propagation process: potential inoculum sources, detection, identification, and management strategies. Plant Disease 95: 1040-1055.

Gramaje D., Di Marco S., 2015. Identifying practices likely to have impacts on grapevine trunk disease infections: a European nursery survey. Phytopathologia Mediterranea 54: 313-324.

Gramaje D., Úrbez-Torres J.R., Sosnowski M. R., 2018. Managing grapevine trunk diseases with respect to etiology and epidemiology: current strategies and future prospects. Plant Disease 102: 12-39.

Grechi I., Vivin P., Hilbert G., Milin S., Robert T., Gaudillère J.-P., 2007. Effect of light and nitrogen supply on internal C:N balance and control of root-to-shoot biomass allocation in grapevine. Environmental and Experimental Botany 59: 139-149.
Grosclaude C., 1993. Pathologie des blessures mettant à nu le bois chez les végétaux ligneux. Agronomie 13: 441-456.

Grosman J., Doublet B., 2012. Maladies du bois de la vigne: synthèse des dispositifs d'observation au vignoble, de l'observatoire 2003-2008 au réseau d’épidémiosurveillance actuel. Phytoma-La Défense des Végétaux 651: 31-35.

Guan X., Essakhi S., Laloue H., Nick P., Bertsch C., Chong J., 2016. Mining new resources for grape resistance against Botryosphaeriaceae: a focus on Vitis vinifera subsp. sylvestris. Plant Pathology 65: 273-284.

Guérard N., Maillard P., Bréchet C., Lieutier F., Dreyer E., 2007. Do trees use reserve or newly assimilated carbon for their defence reactions? A 13C labeling approach with young Scots pines inoculated with a bark-beetle-associated fungus (Ophiostoma brunneo ciliatum). Annals of Forest Science 64: 601-608.

Guérin-Dubrana L., Labenne A., Labrousse J.C., Bastien S., Rey P., Gégout-Petit A., 2012. Statistical analysis of grapevine mortality associated with esca or eutypa dieback foliar expression. Phytopathologia Mediterranea 52: 276-288.

Guérin-Dubrana L., Fontaine F., Mugnai L., 2019. Grapevine trunk disease in European and Mediterranean vineyards: occurrence, distribution and associated disease-affecting cultural factors Phytopathologia Mediterranea 58: 49-71.

Hofstetter V., Buyck B., Croll D., Viret O., Couloux A., Gindro K., 2012. What if esca disease of grapevine were not a fungal disease? Fungal Diversity 54: 51-67.

Kuntzmann P., Villaume S., Larignon P., Bertsch C., 2010. Esca, BDA and Eutypiosis: foliar symptoms, trunk lesions and fungi observed in diseased vinestocks in two vineyards in Alsace. Vitis-Journal of Grapevine Research 49: 71-76.

Lacointe A., 2000. Carbon allocation among tree organs: a review of basic processes and representation in functional-structural tree models. Annals of Forest Science 57: 521-533.

Lafon R., 1921. Modifications à apporter à la taille de la vigne des Charentes, taille Guyot-Poussart mixte et double: lapoplexie, traitement préventif (méthode Poussard), traitement curatif, Roumégous et Déhan, $93 \mathrm{pp}$.

Lamanda N., Roux S., Delmotte S., Merot A., Rapidel B., ... Wery J., 2012. A protocol for the conceptualisation of an agro-ecosystem to guide data acquisition and analysis and expert knowledge integration. European Journal of Agronomy 38: 104-116.

Lambert C., Khiook I.L.K., Lucas S., Télef-Micouleau N., Mérillon J.-M., Cluzet S., 2013. A faster and a stronger defence response: one of the key elements in 
grapevine explaining its lower level of susceptibility to Esca? Phytopathology 103: 1028-1034.

Landi L., Murolo S., Gianfranco R., 2012. Colonization of Vitis spp. Wood by sGFP-Transformed Phaeomoniella chlamydospora, a Tracheomycotic Fungus Involved in Esca Disease. Phytopathology 102: 290-297.

Larignon P., 1990. Contribution à de l'Esca de la vigne: identification des champignons responsables et étude de leur mode d'action. PhD Thesis, University of Bordeaux II, Bordeaux, France, 238 pp.

Larignon P., 2004. Réflexions sur l'esca: Ce que l'on sait déjà montre qu'il en reste beaucoup à apprendre: Vigne. Phytoma-La Défense des Végétaux 576: 28-31.

Larignon P., 2009. Y a-t-il un lien entre climat et expression du Black Dead Arm?: Identification des facteurs climatiques favorisant l'expression des symptômes. Phytoma-La Défense des végétaux 628: 27-29.

Larignon P., 2010. Dépérissement de jeunes plantes: Des symptômes liés au champignon Neofusicoccum parvum déjà connu comme lié au black dead arm sur vignes adultes. Phytoma-La Défense des végétaux 635: $41-46$.

Larignon P., 2011. Vigne, de nouvelles connaissances sur les maladies du bois: Éléments inédits sur la biologie de deux champignons associés, $P$. aleophilum et $D$. seriata. Phytoma-La Défense des végétaux 646: 41-44.

Larignon P., 2016. Maladies cryptogamiques du bois de la vigne: symptomatologie et agents pathogènes (Vol. 2ème édition, pp. 168pp). http://vignevin.com.

Larignon P., 2017. Effect of sodium arsenite on the life cycles of the pathogenic agents involved in wood grapevine diseases. Phytopathologia Mediterranea 56: 537.

Larignon P., Dubos B., 1997. Fungi associated with esca disease in grapevine. European Journal of Plant Pathology 103: 147-157.

Larignon P., Gramaje D., 2015. Life cycle of pathogens. Paper presented at the Abstracts of oral and poster presentation given at the first COST Action FA 1303 workshop on Grapevine Trunk Diseases, Cognac, France, 23-24 June 2015, 420-436.

Larignon P., Fontaine F., Farine S., Clément C., Bertsch C., 2009a. Esca et Black Dead Arm: deux acteurs majeurs des maladies du bois chez la Vigne. Comptes rendus de l'Académie des Sciences- BIOLOGIES 332: 765-783.

Larignon P., Coarer M., Girardon K., Berud F., Jacquet O., 2009b. Propagation of pioneer fungi associated with esca disease by vegetative material in French grapevine nurseries. Phytopathologia Mediterranea 48: 177.

Laveau C., Mary S., Roby J.-P., 2015. Impact du portegreffe sur l'expression des symptômes foliaires de l'esca.
Paper presented at the Les maladies du Bois de la Vigne- Réunion du groupe national Maladies du Bois de la Vigne, Colmar, 17\&18/11/2015.

Lebon G., Wojnarowiez G., Holzapfel B., Fontaine F., Vaillant-Gaveau N., Clément C., 2008. Sugars and flowering in the grapevine (Vitis vinifera L.). Journal of Experimental Botany 59: 2565-2578.

Lecomte P., Leyo M., Louvet G., Corio-Costet M.F., Gaudillere J., Blancard D., 2005. Développement des symptômes de Black Dead Arm: un lien avec la rupture des trajets de sève. Le Progrès agricole et viticole 122: 307-316.

Lecomte P., Darrieutort G., Laveau C., Louvet G., Goutouly J.P., ... Guérin-Dubrana L., 2011. Impact of biotic and abiotic factors on the development of esca decline disease. Paper presented at the «Integrated Protection and Production in Viticulture», 171-180.

Lecomte P., Darrieutort G., Liminana J.M., Comont G., Muruamendiaraz A., ... Fermaud M., 2012. New insights into esca of grapevine: the development of foliar symptoms and their association with xylem discoloration. Plant Disease 96: 924-934.

Lecomte P., Darrieutort G., Liminana J.M., Comont G., Muruamendiaraz A., ... Fermaud M., 2014. Spécial Esca de la Vigne. Phytoma-La Défense des Végétaux, Supplément 674: $22 \mathrm{p}$.

Lecomte P., Diarra B., Carbonneau A., Patrice R., Chevrier C., 2019. Esca of grapevine and training practices in France: results of a 10-year survey. Phytopathologia Mediterranea 57: 472-487.

Lecomte P., Diarra B., Chevrier C., Carbonneau A., 2015. Esca of grapevine and training system. Paper presented at the 19th International Meeting of Viticulture GiESCO, Pech Rouge - Montpellier, 31 May - 5 June 2015, 356-361.

Letousey P., Baillieul F., Perrot G., Rabenoelina F., Boulay M., ... Fontaine F., 2010. Early events prior to visual symptoms in the apoplectic form of grapevine esca disease. Phytopathology 100: 424-431.

Liminana J.-M., Pacreau G., Boureau F., Menard E., David S., ... Dumot V., 2009. Inner necrosis in grapevine rootstock mother plants in the Cognac area (Charentes, France). Phytopathologia Mediterranea 48: 92-100.

Lovisolo C., Perrone I., Hartung W., Schubert A., 2008. An abscisic acid-related reduced transpiration promotes gradual embolism repair when grapevines are rehydrated after drought. New Phytologist 180: 642651.

Magnin-Robert M., Spagnolo A., Alayi T.D., Cilindre C., Mercier L., ... Fontaine F., 2014. Proteomic insights into changes in grapevine wood in response to esca 
proper and apoplexy. Phytopathologia Mediterranea 53: $168-187$.

Magnin-Robert M., Adrian M., Trouvelot S., Spagnolo A., Jacquens L., ... Clément C., 2017. Alterations in grapevine leaf metabolism occur prior to esca apoplexy appearance. Molecular Plant-Microbe Interactions 30: 946-959.

Maher N., Piot J., Bastien S., Vallance J., Rey P., GuérinDubrana L., 2012. Wood necrosis in esca-affected vines: types, relationships and possible links with foliar symptom expression. Journal International des Sciences de la Vigne et du Vin 46: 15-27.

Marchi G., 2001. Susceptibility to esca of various grapevine («Vitis vinifera») cultivars grafted on different rootstock in a vineyard in the Province of Siena (Italy). Phytopathologia Mediterranea 40: 27-36.

Marchi G., Peduto F., Mugnai L., Di Marco S., Calzarano F., Surico G., 2006. Some observations on the relationship of manifest and hidden esca to rainfall. Phytopathologia Mediterranea 45: 117-126.

Martin N., Vesentini D., Rego C., Monteiro S., Oliveira H., Ferreira R. B., 2009. Phaeomoniella chlamydospora infection induces changes in phenolic compounds content in Vitis vinifera. Phytopathologia Mediterranea 48: 101-116.

Martos S., Andolfi A., Luque J., Mugnai L., Surico G., Evidente A., 2008. Production of phytotoxic metabolites by five species of Botryosphaeriaceae causing decline on grapevines, with special interest in the species Neofusicoccum luteum and N. parvum. European Journal of Plant Pathology 121: 451-461.

McArtney S.J., Ferree D.C., 1999. Shading effects on dry matter partitioning, remobilization of stored reserves and early season vegetative development of grapevines in the year after treatment. Journal of the American Society for Horticultural Science 124: 591-597.

McDowell N.G., 2011. Mechanisms linking drought, hydraulics, carbon metabolism, and vegetation mortality. Plant Physiology 155: 1051-1059.

Molot B., Larignon P., Coarer M., 2006. Black dead arm. De nouvelles pistes. Paper presented at the Colloque Mondiaviti, Bordeaux, 29-30 novembre 2006, 15-17.

Mondello V., Songy A., Battiston E., Pinto C., Coppin C., ... Fontaine F., 2018. Grapevine trunk diseases: a review of fifteen years of trials for their control with chemicals and biocontrol agents. Plant Disease 102: 1189-1217.

Mondello V., Larignon P., Armengol J., Kortekamp A., Vaczy K., ... Fontaine F., 2019. Management of grapevine trunk diseases: knowledge transfer, current strategies and innovative strategies adopted in Europe. Phytopathologia Mediterranea 57: 369-383.
Moret F., Lemaître-Guillier C., Grosjean C., Clément G., Coelho C., ... Adrian M., 2019. Clone-Dependent Expression of Esca Disease Revealed by Leaf Metabolite Analysis. Frontiers in Plant Science 9: 1-12.

Morvan G., Grosjean C., Petitot P., Dureuil J., 2011. Lettre Maladies du Bois n ${ }^{\circ}, 8 \mathrm{pp}$.

Morvan G., Grosjean C., Petitot P., Dureuil J., 2012. Vrai/ Faux: l'ébourgeonnage favorise $t$ il l'esca? Lettre Maladies $d u$ Bois 3: 1-2.

Mugnai L., Graniti A., Surico G., 1999. Esca (black measles) and brown wood-streaking: two old and elusive diseases of grapevines. Plant Disease 83: 404418.

Murolo S., Romanazzi G., 2014. Effects of grapevine cultivar, rootstock and clone on esca disease. Australasian Plant Pathology 43: 215-221.

Mutawila C., Fourie P.H., Haleen F., Mostert L., 2011. Histo-pathology study of the growth of Trichoderma harzianum, Phaeomoniella chiamydospora and Eutypa lata on grapevine pruning wounds. Phytopathologia Mediterranea 50 (Supplement): S46-S60.

Oliva J., Stenlid J., Martínez-Vilalta J., 2014. The effect of fungal pathogens on the water and carbon economy of trees: implications for drought-induced mortality. New Phytologist 203: 1028-1035.

Oliveira H., Freitas R., Rego C., Ferreira R.B., 2009. Interactions among grapevine disease-causing fungi. The role of reactive oxygen species. Phytopathologia Mediterranea 48: 117-127.

Osti F., Di Marco S., 2010. Iron-dependant, non enzymatic processes promoted by Phaeomoniella chlamydospora and Phaeoacremonium aleophilum, agents of esca in grapevine. Physiological and Molecular Plant Pathology 74: 309-316.

Pearce R.B., 1996. Antimicrobial defences in the wood of living trees. New Phytologist 132: 203-233.

Pearce R.B., 2000. Decay development and its restriction in trees. Journal of Arboriculture 26: 1-11.

Pellegrino A., Gozé E., Lebon E., Wery J., 2006. A model-based diagnosis tool to evaluate the water stress experienced by grapevine in field sites. European Journal of Agronomy 25: 49-59.

Péros J.P., 1995. Sensibilité des cepages à l'eutypiose: le problème du comportement de référence au vignoble. Progrès Agricole et Viticole 112: 61-67.

Petit A.N., Vaillant N., Boulay M., Clément C., Fontaine F., 2006. Alteration of photosynthesis in grapevines affected by esca. Phytopathology 96: 1060-1066.

Pierron R., 2015. Esca et vigne: compréhension des mécanismes de défense précoces du bois de la vigne Vitis vinifera L. suite à la maladie, colonisation des champignons in planta et proposition de moyens de lutte 
pour une viticulture durable. $\mathrm{PhD}$ Thesis, University of Toulouse, Toulouse, France, $228 \mathrm{pp}$.

Pinto C., Pinho D., Sousa S., Pinheiro M., Egas C., C. Gomes A., 2014. Unravelling the diversity of grapevine microbiome. PLoS ONE 9: e85622.

Piou D., Nageleisen L.M., Desprez-Loustau M.L., Candau J.N., 2006. Les risques sanitaires consécutifs à 2003 à la lumière de la littérature. $R D V$ techniques 11: 28-34.

Pontini S., Fleurat-Lessard P., Béré E., Berjeaud J.-M., Roblin G., 2014. Impact of temperature variations on toxic effects of the polypeptides secreted by Phaeoacremonium aleophilum. Physiological and Molecular Plant Pathology 87: 51-58.

Pouzoulet J., 2012. Développement d'une méthodologie PCR en temps réel pour la détection et la quantification in planta des principaux champignons pathogènes associés aux maladies du bois de la vigne. $\mathrm{PhD}$ Thesis, University of Toulouse, Toulouse, France, $176 \mathrm{pp}$.

Pouzoulet J., Jacques A., Besson X., Dayde J., Mailhac N.H., 2013. Histopathological study of response of Vitis vinifera cv. Cabernet Sauvignon to bark and wood injury with and without inoculation by Phaeomoniella chlamydospora. Phytopathologia Mediterranea 52: 313-323.

Pouzoulet J., Pivovaroff A.L., Santiago L.S.,,Rolshausen P.E., 2014. Can vessel dimension explain tolerance toward fungal vascular wilt diseases in woody plants? Lessons from Dutch elm disease and esca disease in grapevine. Frontiers in Plant Science 5: 1-11.

Reis P., Alves A., Fontaine F., Lourenço I., Saramago J., Rego C., 2019. Early season symptoms on grapevine stem and inflorescences associated with Botryosphaeriacea species. Phytopathologia Mediterranea 58: 398-399.

Reis P., Magnin-Robert M., Nascimento T., Spagnolo A., Abou-Mansour E., ... Fontaine F., 2016. Reproducing Botryosphaeria dieback foliar symptoms in a simple model system. Plant Disease 100: 1071-1079.

Rey P., Lecomte P., Guérin-Dubrana L., Corio-Costet M.-F., Fontaine F., ... de la Roque B., 2011. Maladies $\mathrm{du}$ bois de la vigne situation, enjeux et perspective. Phytoma-La Défense des Végétaux 640: 22-26.

Rolshausen P.E., Greve L.C., Labavitch J.M., Mahoney N.E., Molyneux R.J., Gubler W.D., 2008. Pathogenesis of Eutypa lata in grapevine: identification of virulence factors and biochemical characterization of cordon dieback. Phytopathology 98: 222-229.

Rudelle J., Octave S., Kaid-Harche M., Roblin G., FleuratLessard P., 2005. Structural modifications induced by Eutypa lata in the xylem of trunk and canes of Vitis vinifera. Functional Plant Biology 32: 537-547.
Schoeneweiss D.F., 1981. Infectious diseases of trees associated with water and freezing stress. Journal of arboriculture 7: 13-19.

Schwarze F.W.M.R., Baum S., 2000. Mechanisms of reaction zone penetration by decay fungi in wood of beech (Fagus sylvatica). New Phytologist 146: 129-140.

Shain L., 1971. The response of sapwood of Norway spruce to infection by Fomes annosus. Phytopathology 61: 301-307.

Shani U., Waisel Y., Eshel A., Xue S., Ziv G., 1993. Responses to salinity of grapevine plants with split root systems. New Phytologist 124: 695-701.

Shigo A.L., 1979. Tree decay an expanded concept. United States Department of Agriculture Forest Service. Agriculture information Bulletin number 419 (Avril 1979).

Silpi U., Lacointe A., Kasempsap P., Thanysawanyangkura S., Chantuma P., ... Thaler P., 2007. Carbohydrate reserves as a competing sink: evidence from tapping rubber trees. Tree Physiology 27: 881-889.

Simonit M., Deledda F., Giudici M., Manfreda L., Ostan M., ... Zanutta A., 2012. Potatura ramificata della vite L'Informatore agrario 35-46..

Smith K.T., 2015. Compartmentalization, resource allocation, and wood quality. Current Forestry Reports 1: 8-15.

Songy A., Fernandez O., Clément C., Larignon P., Fontaine F., 2019. Grapevine trunk diseases under thermal and water stresses. Planta 249: 1655-1679.

Sosnowski M.R., Lardner R., Wicks T., Scott E.S., 2007. The influence of grapevine cultivar and isolate of Eutypa lata on wood and foliar symptoms. Plant Disease 91: 924-931.

Sosnowski M.R., Luque J., Loschiavo A., Martos S., Garcia-Figueres F., ... Scott E., 2011. Studies on the effect of water and temperature stress on grapevines inoculated with Eutypa lata. Phytopathologia Mediterranea 50: 127-138.

Spagnolo A., Marchi G., Peduto F., Phillips A.J., Surico G., 2011. Detection of Botryosphaeriaceae species within grapevine woody tissues by nested PCR, with particular emphasis on the Neofusicoccum parvum/N. ribis complex. European Journal of Plant Pathology 129: 485-500.

Spagnolo A., Magnin-Robert M., Alayi T.D., Cilindre C., Mercier L., ... Fontaine F., 2012. Physiological changes in green stems of Vitis vinifera L. cv. Chardonnay in response to esca proper and apoplexy revealed by proteomic and transcriptomic analyses. Journal of Proteome Research 11: 461-475.

Spagnolo A., Larignon P., Magnin-Robert M., Hovasse A., Cilindre C., ... Fontaine F., 2014a. Flowering as the 
most highly sensitive period of grapevine (Vitis vinifera L. cv Mourvèdre) to the Botryosphaeria dieback agents Neofusicoccum parvum and Diplodia seriata infection. International Journal of Molecular Sciences 15: 9644-9669.

Spagnolo A., Magnin-Robert M., Alayi T.D., Cilindre C., Schaeffer-Reiss C., ... Fontaine F., 2014b. Differential responses of three grapevine cultivars to Botryosphaeria dieback. Phytopathology 104: 1021-1035.

Spagnolo A., Wu H., Chollet J.F., Clément C., Fontaine F., 2015. Maladies du bois de la vigne: mise au point d'un modèle simplifié en vue de tester des moyens de lutte. Paper presented at the Les maladies du Bois de la vigne, Colmar, 17 et 18/11/15, 48.

Spagnolo A., Mondello V., Larignon P., Villaume S., Rabenoelina F., ... Fontaine F., 2017. Defence responses in grapevine (cv. Mourvèdre) after inoculation with the Botryosphaeria dieback pathogens Neofusicoccum parvum and Diplodia seriata and their relationship with flowering. International Journal of Molecular Sciences 18: 393.

Sparapano L., Bruno G., Graniti A., 2000. Effects on plants of metabolites produced in culture by Phaeoacremonium chlamydosporum, $P$. aleophilum and Fomitiporia punctata. Phytopathologia Mediterranea 39: $169-177$.

Sparapano L., Graniti A., Bruno G., 2001. Three-year observation of grapevines cross-inoculated with escaassociated fungi. Phytopathologia Mediterranea 40: 376-386.

Stamp N., 2003. Out of the quagmire of plant defence hypotheses. The Quarterly Review of Biology 78: 23-55.

Surico G., 2009. Towards a redefinition of the diseases within the esca complex of grapevine. Phytopathologia Mediterranea 48: 5-10.

Surico G., Marchi G., Mugnai L., Braccini P., 2000. Epidemiology of esca in some vineyards in Tuscany (Italy). Phytopathologia Mediterranea 39: 190-205.

Surico G., Marchi G., Mugnai L., D’Ovidio R., Roberti S., 2001. Pectic Enzymes Production by «Phaeomoniella chlamydospora». Phytopathologia Mediterranea 40: 407-416.

Surico G., Mugnai L., Marchi G., 2006. Older and more recent observations on esca: a critical overview. Phytopathologia Mediterranea 45: 68-86.

Thibault M., 2015. Le curetage. Paper presented at the Les maladies du Bois de la Vigne- Réunion du groupe national Maladies du Bois de la Vigne, Colmar, $17-18 / 11 / 2015$.

Travadon R., Lecomte P., Diarra B., Lawrence D.P., Renault D., ... Baumgartner K., 2016. Grapevine pruning systems and cultivars influence the diversity of wood-colonizing fungi. Fungal Ecology 24: 82-93.

Troccoli L., Mori B., Surico G., Mugnai L., Calamassi R., 2001. "Phaeomoniella chlamydospora»-Grapevine interaction: histochemical reactions to fungal infection. Phytopathologia Mediterranea 40: 400-406.

Tyree M.T., Sperry J.S., 1989. Vulnerability of xylem to cavitation and embolism. Annual Review of Plant Biology 40: 19-36.

Úrbez-Torres J.R., 2011. The status of Botryosphaeriaceae species infecting grapevines. Phytopathologia Mediterranea 50 (Supplement): S5-S45.

Úrbez-Torres J.R., Haag P., Bowen P., O'Gorman D.T., 2014. Grapevine trunk diseases in British Columbia: incidence and characterization of the fungal pathogens associated with esca and petri diseases of grapevine. Plant Disease 98: 469-482.

Valtaud C., Larignon P., Roblin G., Fleurat-Lessard P., 2009. Developmental and ultrastructural features of Phaeomoniella chlamydospora and Phaeoacremonium aleophilum in relation to xylem degradation in esca disease of the grapevine. Journal of Plant Pathology 91: 37-51.

Valtaud C., Thibault F., Larignon P., Bertsch C., FleuratLessard P., Bourbouloux A., 2011. Systemic damage in leaf metabolism caused by esca infection in grapevines. Australian Journal of Grape and Wine Research 17: 101-110.

van Niekerk J., Fourie P.H., Hallenn F., Crous P., 2006. Botryosphaeria spp. as grapevine trunk disease pathogens. Phytopathologia Mediterranea 45: 43-54.

van Niekerk J., Strever A.E., Du Toit G.P., Halleen F., Fourie P.H., 2011. Influence of water stress on Botryosphaeriaceae disease expression in grapevines. Phytopathologia Mediterranea 50: 151-165.

Vigues V., Serrano E., Dumas C., Coarer M., Yobregat O., Larignon P., 2007. Les maladies du bois peuvent commencer en pépinières: Contaminations des plants de vignes par les champignons associés aux maladies du bois, une enquête en Midi-Pyrénées. Phytoma-La Défense des Végétaux 609: 20-23.

Vigues V., Yobregat O., Mille B., Berud F., Ayme-Sevenier V., ... Larignon P., 2012. Maladie du bois, gros plan sur les greffons et porte-greffes en entrée de pépinière. Phytoma-La Défense des végétaux 658: 26-28.

Vigues V., Yobregat O., Barthélémy B., Dias F., Coarer M., Philippe L., 2013. Les champignons associés aux Maladies du Bois: identification des étapes à risque en pépinière. In: Vignevin Sud Ouest (Ed.), pp. 2.

Viiri H., Niemelä P., Kitunen V., Annila E., 2001. Soluble carbohydrates, radial growth and vigour of fertilized 
Norway spruce after inoculation with blue-stain fungus, Ceratocystis polonica. Trees 15: 327-334.

Wagschal I., Abou-Mansour E., Petit A.N., Clément C., Fontaine F. 2008. Wood diseases of grapevine: a review on eutypa dieback and esca. In: Plant-Microbe interactions. Research signpost (Ait-Barka E., Clément C., ed.), 367-391.

Wargo P.M., 1996. Consequences of environmental stress on oak: predisposition to pathogens. Annals of Forest Science 53: 359-368.

Yacoub A., Gerbore J., Magnin N., Chambon P., Dufour M.-C., ... Rey P., 2016. Ability of Pythium oligandrum strains to protect Vitis vinifera L., by inducing plant resistance against Phaeomoniella chlamydospora, a pathogen involved in Esca, a grapevine trunk disease. Biological Control 92: 7-16.

Yadeta K.A., Thomma B.P., 2013. The xylem as battleground for plant hosts and vascular wilt pathogens. Frontiers in Plant Science 4: 1-12.

Yobregat O., Larignon P., Mille B., Bloy P., Carcenac D., ... Charlot S., 2018. Etude de la cinétique de contamination de jeunes plants par les champignons responsables des maladies $d u$ bois. Paper presented at the V'innoDAY 2018, Toulouse, France, 11 janvier 2018, 21-25.

Yobregat O., Abidon C., 2019. Le curetage des souches: résultats récents pour une technique ancienne. Paper presented at the 4èmes assises des vins du Sud-Ouest, France, 24 janvier 2019, 55-59.

Zufferey V., Cochard H., Ameglio T., Spring J.L., Viret O., 2011. Diurnal cycles of embolism formation and repair in petioles of grapevine (Vitis vinifera cv. Chasselas). Journal of Experimental Botany 62: 38853894. 